FFR 211996

$$
\text { OSTI }
$$

OAK RIDGE NATIONAL LABORATORY

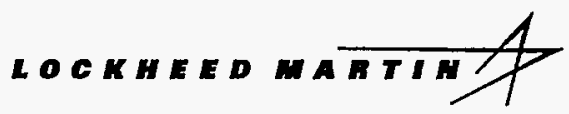

\section{Methods to Estimate Stranded Commitments for a Restructuring U.S. Electricity Industry}

MANAGED BY

LOCKHEED MARTIN ENERGY SYSTEMS, INC. FOR THE UNITED STATES DEPARTMENT OF ENERGY
Eric Hirst

Stan Hadley

Lester Baxter

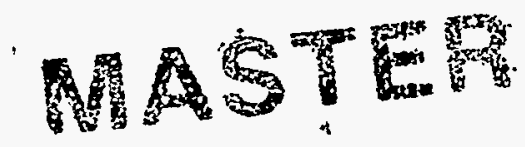

DISTAIBUTION OF THIS DOCURENT IS UALHATED 
This report has been reproduced directly from the best available copy.

Available to DOE and DOE contractors from the Office of Scientific and Technical Information, P.O. Box 62, Oak Ridge, TN 37831; prices available from (615) 576-8401, FTS 626-8401.

Available to the public from the National Technical Information Service, U.S. Department of Commerce, 5285 Port Royal Rd., Springfield, VA 22161.

This report was prepared as an account of work sponsored by an agency of the United States Government. Neither the United States Government nor any agency thereof, nor any of their employees, makes any warranty, express or implied, or assumes any legal liability or responsibility for the accuracy, completeness, or usefulness of any information, apparatus, product, or process disclosed, or represents that its use would not infringe privately owned rights. Reference herein to any specific commercial product, process, or service by trade name, trademark, manufacturer, or otherwise, does not necessarily constitute or imply its endorsement, recommendation, or favoring by the United States Government or any agency thereof. The views and opinions of authors expressed herein do not necessarily state or reflect those of the United States Government or any agency thereof. 
ENERGY DIVISION

\section{METHODS TO ESTIMATE STRANDED COMMITMENTS FOR A RESTRUCTURING U.S. ELECTRICITY INDUSTRY}

ERIC HIRST, STAN HADLEY, AND LESTER BAXTER

January 1996

Sponsored by

Competitive Resource Strategies Program

Office of Energy Efficiency and Renewable Energy

U.S. Department of Energy

OAK RIDGE NATIONAL LABORATORY

Oak Ridge, Tennessee 37831

managed by

LOCKHEED MARTIN ENERGY RESEARCH CORPORATION

for the

U.S. DEPARTMENT OF ENERGY

under contract No. DE-AC05-84OR22464 



\section{CONTENTS}

\section{Page}

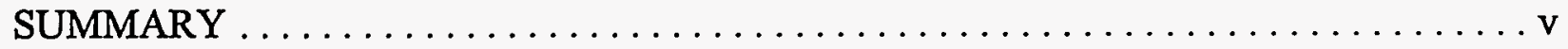

LIST OF ACRONYMS $\ldots \ldots \ldots \ldots \ldots \ldots \ldots \ldots \ldots \ldots \ldots \ldots \ldots \ldots \ldots \ldots \ldots$ vii

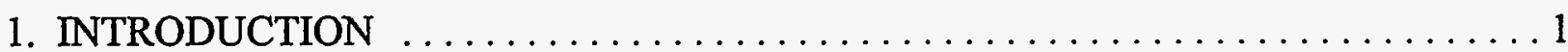

2. KEEP-SALE AND LOSE-SALE CONCEPTS $\ldots \ldots \ldots \ldots \ldots \ldots \ldots \ldots \ldots \ldots \ldots \ldots \ldots$

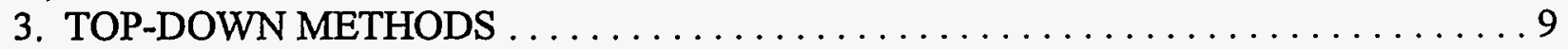

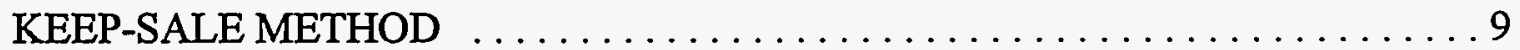

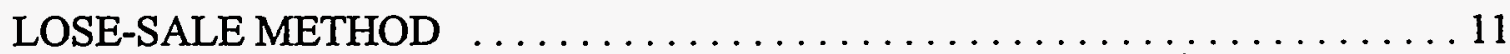

4. BOTTOM-UP METHODS . . . . . . . . . . . . . . . . . . . . . . . . . . 15

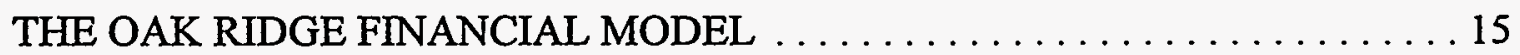

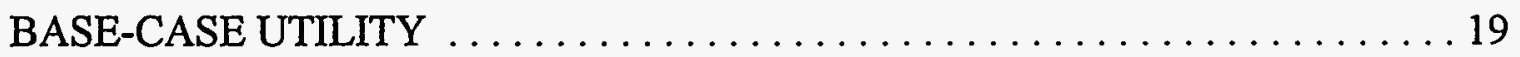

5. FACTORS THAT AFFECT STRANDED-COMMITMENT AMOUNTS $\ldots \ldots \ldots \ldots 25$

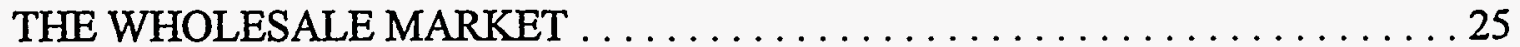

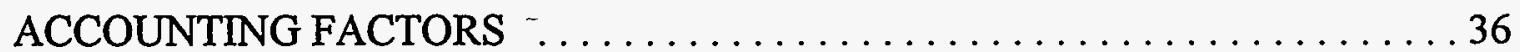

6. WHEN IS IT BETTER TO KEEP THE SALE? . . . . . . . . . . . . . . . . . . . 39

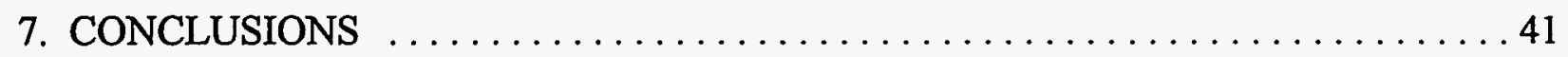

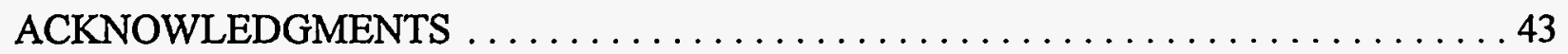

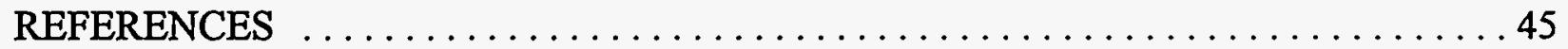





\section{SUMMARY}

Estimates of stranded commitments for U.S. investor-owned electric utilities range widely, from as little as $\$ 20$ billion to as much as $\$ 500$ billion (more than double the shareholder equity in U.S. utilities). These potential losses are a consequence of the abovemarket book values for some utility-owned power plants, long-term power-purchase contracts, deferred income taxes, regulatory assets, and public-policy programs.

Because of the wide range of estimates and the potentially large dollar amounts involved, state and federal regulators need a clear understanding of the methods used to calculate these estimates. In addition, they may want simple methods that they can use to check the reasonableness of the estimates that utilities and other parties present in regulatory proceedings.

This report explains various top-down and bottom-up methods to calculate stranded commitments. The purpose of this analysis is to help regulators and others understand the implications of different analytical approaches to estimating stranded-commitment amounts. Top-down methods, because they use the utility as the unit of analysis, are simple to apply and to understand. However, their aggregate nature makes it difficult to determine what specific assets and liabilities affect their estimates. Bottom-up methods use the individual asset (e.g., power plant) or liability (e.g., power-purchase contract, fuel-supply contract, and deferred income taxes) as the unit of analysis. These methods have substantial data and computational requirements.

A utility can react to the potential loss of retail customers in two ways. It could lose the sale and then seek to resell some or all of the lost sales on the wholesale market. Or it could lower its price for the at-risk customers to the wholesale price and thereby keep the sale. These two options, keep sale or lose sale, often yield very different estimates of stranded commitments. In principle, regulators could cap utility recovery at the smaller of these two amounts.

Estimates of stranded commitments for the keep-sale and lose-sale options depend strongly on interactions between the utility's generating assets (both utility-owned units and its long-term power-purchase contracts) and the wholesale power market but in different ways (Table S-1). The key wholesale-market factors affecting stranded-commitment estimates are wholesale prices, utility marginal production costs, transmission capacity, the percentage of retail load at risk, and the difference between wholesale purchase and sale prices. 
Table S-1. The effects of increases in different factors related to wholesale power markets on estimates of stranded commitments

\begin{tabular}{lll}
\hline $\begin{array}{l}\text { Factor } \\
\text { increasing }\end{array}$ & \multicolumn{2}{c}{ Effect on stranded commitments if utility: } \\
\hline $\begin{array}{l}\text { Wholesale } \\
\text { prices }^{\mathrm{a}}\end{array}$ & Decreases & \multicolumn{1}{c}{ Loses sale } \\
$\begin{array}{l}\text { Transmission } \\
\text { capacity }\end{array}$ & Decreases & $\begin{array}{l}\text { Decreases; nearly independent of } \\
\text { wholesale prices at low values of } \\
\text { transmission capacity } \\
\text { Decreases for high values of retail } \\
\text { wheeling and at high wholesale prices; } \\
\text { increases at low values of retail wheeling } \\
\text { and at low wholesale prices }\end{array}$ \\
$\begin{array}{l}\text { Percentage of } \\
\text { customers that } \\
\text { wheel }\end{array}$ & $\begin{array}{l}\text { Increases linearly with } \\
\text { number of wheeling }\end{array}$ & $\begin{array}{l}\text { Increases more rapidly than number of } \\
\text { wheeling customers }\end{array}$ \\
$\begin{array}{l}\text { Difference } \\
\text { between } \\
\text { wholesale } \\
\text { purchase and } \\
\text { sale prices }\end{array}$ & $\begin{array}{l}\text { No change at low } \\
\text { wholesale prices; increases } \\
\text { at high wholesale prices }\end{array}$ & $\begin{array}{l}\text { No change at low wholesale prices; } \\
\text { increases at high wholesale prices }\end{array}$ \\
\hline
\end{tabular}

${ }^{\text {a }}$ The response to increases in the utility's marginal costs of generation is exactly the opposite of those for increases in wholesale prices.

Not all the factors affecting stranded-commitment estimates are related to wholesale markets; several depend on accounting. These accounting factors include the fixed costs associated with a utility's power plants and power-purchase contracts, deferred income taxes, regulatory assets, public-policy programs, inflation rate, and tax rates. These accounting factors affect stranded commitments through the details of rate design.

Because the keep-sale option is largely independent of wholesale markets, top-down methods yield accurate estimates of stranded commitments for this option. However, the topdown methods do poorly in estimating the amount of stranded commitment if the utility loses the sale, because of complications in analyzing wholesale-market interactions. 


\section{LIST OF ACRONYMS}

A\&G Administrative and general

BU Bottom up

$\mathrm{C} / \mathrm{I} \quad$ Commercial and industrial

$\Delta \mathrm{kWh}$ WS Change in wholesale sales because of retail wheeling

$\Delta$ WS-price Difference between wholesale purchase and sale prices

EIA Energy Information Administration

j Subscript denoting customer classes

KS Keep sale

$\mathrm{kWh} \mathrm{RW}_{\mathrm{RW}} \quad$ Annual electricity sales lost to retail wheeling

LS Lose sale

MC Marginal production cost in $\notin / \mathrm{kWh}$

NPV Net present value

ORFIN Oak Ridge Financial Model

O\&M Operations and maintenance

RW Retail wheeling

SC Stranded commitments

$t \quad$ Subscript denoting time in years

TD Top down

T\&D Transmission and distribution 



\section{INTRODUCTION}

Stranded commitments (SC) are the monetary losses that electric-utility shareholders (or other parties) might experience because of structural and regulatory changes in the electricity industry. In essence, the retail monopoly franchise that investor-owned utilities enjoy today permits them, with approval from the state regulatory commission, to charge customers for all the costs of producing and delivering electricity. In a competitive electricity market, the frequent interactions of buyers and sellers, rather than regulators, will set prices. If these market prices are below embedded costs, then stranded commitments will occur.

A full treatment of SC would consider (1) alternative ways to calculate SC; (2) estimates of the amount of SC for an individual utility; (3) methods to mitigate these amounts; and (4) allocation of the remaining SC among utility shareholders, different classes of customers, independent power producers, and governments (i.e., taxpayers in general). This report focuses on topic 1 ; we also examine the factors that affect the amounts calculated, topic 2.

We focus on methods for three reasons. First, the estimate of SC one obtains depends strongly on the method used to develop that estimate. Nationwide, these estimates typically range from $\$ 50$ to $\$ 150$ billion (Baxter and Hirst 1995); such differences are caused, in part, by 'the use of different analytical methods. Second, the literature provides few details on different estimation methods. Third, regulators need simple methods that they can use to check the reasonableness of the results that their utilities present them. For example, the Vermont Competition Work Group (1995) stated "During the next phase of this process, work should be done to identify, categorize, and quantify the net above-market transition costs ... ." And the staff of the New York Public Service Commission (1995) called stranded commitments "the single largest obstacle to electric competition."

San Diego Gas \& Electric (1994) developed a useful typology of methods to estimate SC. As detailed by Baxter (1995), this framework considers three categories: administrative vs market valuation, ex ante vs ex post valuation, and top-down (TD) vs bottom-up (BU) valuation. We focus on ex ante administrative approaches and consider both TD and BU methods.

A BU, ex ante, administrative approach would involve calculation of the unit-by-unit performance of each of a utility's power plants in a hypothesized competitive generation market. Calculating the return provided by each generating unit involves detailed productioncost simulations for both the utility in question and the surrounding utilities and independent power producers. These simulations would show the number of hours each year that each generating unit operates, its variable production costs, the market price of power that hour, and, 
from these numbers, the profitability of each unit. Such calculations require thousands of assumptions concerning present and future customer locations, loads, load shapes, and peak loads; transmission-system operation, expansion, constraints, costs, and pricing rules; operating costs and performance of all existing and new generating units; fuel prices; government decisions on siting and environmental restrictions for new power plants and transmission lines; and so on. A bottom-up analysis requires similarly detailed calculations of stranded liabilities (especially power-purchase and fuel-supply contracts), regulatory assets, and public-policy programs. The method developed and applied by Resource Data International (1994) is probably the leading example of a BU method.

The TD approach is the opposite of the BU approach. Rather than using the individual asset or liability as the unit of observation, it treats the utility as the unit of observation. (Intermediate methods that use different groups of assets and liabilities as the unit of observation are also possible.) In a TD, ex ante, administrative approach, the utility's average embedded cost of electricity production is compared with an average assumed market price. This approach is much simpler than the BU approach, primarily because it requires only a few assumptions and elementary calculations. However, it is also much less detailed and, therefore, provides fewer insights into the specific assets, liabilities, and costs that account for a utility's SC situation. The Federal Energy Regulatory Commission (1995) proposed such an approach to estimate $\mathrm{SC}$ at the wholesale level.

A key issue facing regulators is the usefulness of TD methods. If these methods yield accurate and reliable results (i.e., if their results are consistent with those produced by BU methods), then commissions can avoid the complications and controversies associated with the data-intensive and computationally burdensome BU methods. If, on the other hand, the TD methods produce results that are biased, inaccurate, or both, their usefulness will be greatly limited. We examine the performance of TD methods, in particular the range of variables where they perform well and where they do not.

The accuracy of TD methods depends largely on how the utility responds to retail competition. Faced with retail competition, a utility can lose the sale (LS) or it can lower its price to keep the sale (KS). Analytically, computing the $\mathrm{KS}$ value of SC is simple; indeed the TD and BU methods yield identical results for the KS option. However, calculating SC for the LS option is much more complicated because its value depends on how the utility's power plants and power-purchase contracts interact with the wholesale market. Because interactions with the wholesale market dominate analysis of the LS option, we devote considerable attention to how these factors affect SC estimates and the performance of various TD-LS approaches. We also identify those factors that affect the amount of SC and whether or not they depend on wholesale-market interactions. Such analyses are important because the KS and LS estimates of SC can differ substantially. 
We use an expanded version of the Oak Ridge Financial Model (ORFIN) to examine these analytical issues (Hirst and Hadley 1994). ORFIN is a spreadsheet model that simulates an electric-utility's financial operations. It includes an annual income statement and balance sheet. We added a production-costing module to ORFIN to simulate operation of a utility's portfolio of generating resources (both utility-owned plants and power-purchase contracts) and how that portfolio interacts with an exogenously specified wholesale power market. ORFIN now includes all the TD and BU approaches that we consider relevant to the analysis of SC issues.

This report will help state and federal regulators as they review the claims for SC submitted to them by utilities and other parties. Chapter 2 explains the concepts of stranded commitments, including the KS and LS options and the importance of the wholesale market in calculating SC amounts with LS methods. Chapter 3 explains TD methods, while Chapter 4 describes how ORFIN is used to conduct BU analyses. Chapter 5 shows how various wholesale-market and accounting factors affect the KS and LS estimates of SC. Chapter 6 recasts the results of Chapter 5 in terms of the conditions under which the KS option is preferred. Finally, Chapter 7 summarizes our findings concerning the strengths and limitations of the TD and BU methods and offers suggestions to regulatory commissions on suitable methods for calculating stranded commitments. 


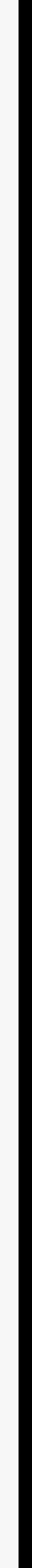




\section{KEEP-SALE AND LOSE-SALE CONCEPTS}

The amount of stranded commitments a utility experiences ${ }^{*}$ depends in part on the utility's actions, specifically whether the utility keeps or loses the sale. In both cases, the utility will continue to recover from retail-wheeling customers the full costs of providing them with transmission and distribution (T\&D) services.

If the utility keeps the sale, its loses revenue in two ways. First, for those customers that wheel, it loses the difference between its embedded cost of generation and the market price of power. Second, it may experience losses associated with rate-design differences in cost allocation and subsidies, if any, among retail customer classes.

If the utility loses the sale, its revenue loss consists of three factors. The first factor is the product of the retail sales at risk and the difference between the utility's embedded cost of generation for those customers that wheel and its marginal cost of production (MC). The second factor is the possible revenue gains from the sale of some or all of the lost sales on the wholesale market, based on the difference between the utility's $\mathrm{MC}$ and the price it can get on the wholesale market. The fraction of lost sales that the utility can resell and the profitability of doing so depend on the utility's MC and the available capacity for each generating unit, wholesale prices, and transmission constraints and prices. The third factor is the same as the second factor in the KS option, losses associated with rate design. The complications in determining SC with the LS method are with the second factor, the utility's interaction with the wholesale market.

Figure 1 shows, in a simplified way, how a utility interacts with its surrounding wholesale market. The solid line represents the MC of the utility's power plants and powerpurchase contracts. Marginal costs increase with increasing output, because the utility will dispatch its cheapest plants first.

The two dashed lines in Fig. 1 represent the wholesale purchase and sale prices at which the utility can buy or sell power on the spot market; we assume that the spot and wholesale markets are identical. The figure shows purchase price higher than sale price, which would be the case if the utility has to pay for losses or other ancillary services when selling on the spot

*In practice, the SC losses are likely to be shared among utility shareholders, customers, other stakeholders, and taxpayers. We concentrate on the utility in this report only for convenience because our focus is on methods to calculate SC amounts, not on ways to allocate these losses among different groups. 
market. The two vertical lines mark the boundaries of the regions in which the utility will sell or buy on the spot market.
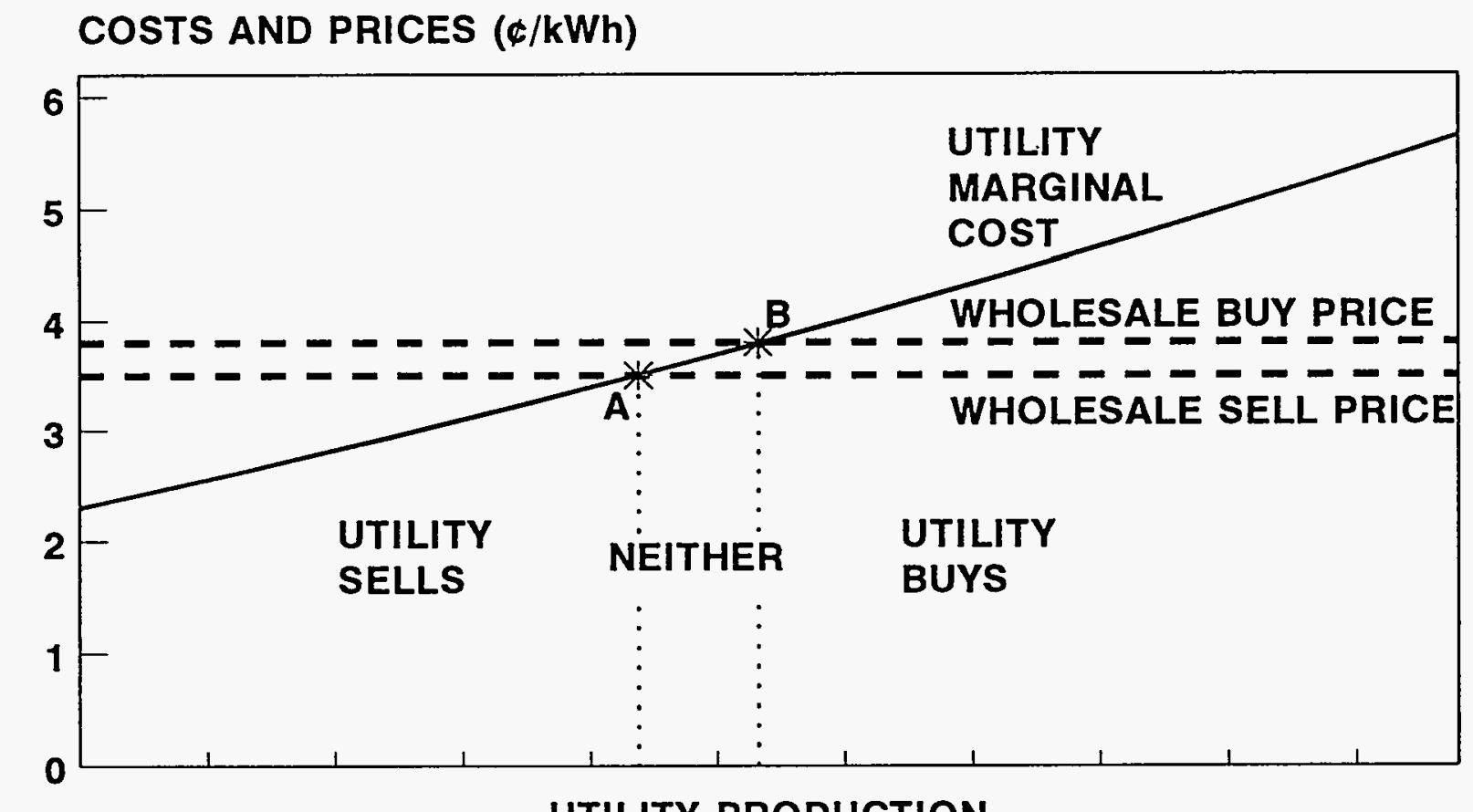

Fig. 1. Schematic showing relationship between a utility's marginal production costs and wholesale prices.

To the left of the first vertical line, the utility will increase the output from its generating units beyond what it needs to meet its native-load requirements and will sell the excess on the spot market. It will increase production only up to point A; to the right of A, the utility's MC exceeds the price it receives for spot sales.

Between points $\mathrm{A}$ and $\mathrm{B}$, the utility neither sells to nor buys from the spot market. Within this range of output, the utility's MC is between the wholesale sale and buy prices. To the right of point $\mathrm{B}$, the utility will reduce the output of its generating units and will meet some of its native-load requirements by buying on the spot market.

Retail wheeling (RW) moves the utility's production to the left along the solid line. This reduces the utility's need to buy power (if native-load requirements are to the right of point $B$ ) or increases its opportunity to sell power (if native-load requirements are to the left of point A). Thus, the reduction in native-load requirements caused by wheeling affects the utility's incentives to buy or sell on the spot market.

At first glance, one might consider the lose-sale option unrealistic. If the utility can sell at wholesale and make money doing so, why could it not keep the retail-wheeling customers? 
There are several reasons why both options are, under differing circumstances, viable. First, when the utility loses a sale, the departing customer may have various reasons for purchasing from another entity that go beyond the difference between the utility's embedded-cost price and the wholesale price of electricity. Second, when the utility loses a retail sale, it is no longer obligated to meet the year-round, hour-by-hour loads of that customer. It can pick and choose the times during which it will sell this "surplus" power on the spot market. Third, transmission losses and congestion might limit a utility's ability to interact with the spot market. Finally, a utility's corporate policy may limit its willingness to offer customers a discount.

In reality, the situation is more complicated than described here, as explained in Chapters 3 through 5. Briefly, the utility's ability to buy and sell on the spot market may be limited by transmission constraints or, when selling, by generation constraints (the amount of extra generating capacity available with variable costs below the wholesale sale price). Also, given the range of MCs and wholesale prices, the utility is likely to be buying and selling at different times of the same year.

In addition, utility actions and electric-industry restructuring are likely to affect wholesale prices over time, and therefore SC amounts. For example, a decision to maintain a predetermined amount of extra generating reserves (planning reserve) would increase the contribution to fixed costs for those units that provide this service and would reduce spotmarket energy revenues. If competition encourages the operators of generating units to achieve higher availability factors, energy revenues will increase, but capacity prices will drop. We did not try to incorporate such dynamic interactions between wholesale markets and industry structure into our analysis. 


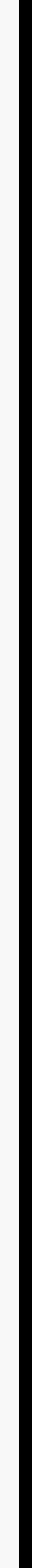




\section{TOP-DOWN METHODS}

The general strengths of the TD method are its requirement for only limited amounts of data and its use of simple calculations that can be readily understood. These strengths lead to fewer assumptions to litigate than with a BU approach. On the other hand, the TD approach, because of its aggregation, cannot identify the relationship between the amount of SC computed and any particular asset. Also, TD approaches may be less accurate than BU approaches, as shown later in this chapter.

The amount of SC that a utility experiences will depend on whether or not the utility keeps or loses the sales that are at risk because of retail wheeling. In principle, the amount of $\mathrm{SC}$ that a utility might be allowed to recover from customers should be limited to the smaller of these two amounts. In other words, if it costs the utility less to retain the at-risk customers, then it should do so. On the other hand, if it costs less to let the customers depart, then the utility should do that.

\section{KEEP-SALE METHOD}

For the KS method, the earnings loss to the utility from $\mathrm{SC}$ is:

$$
\begin{aligned}
& \text { T N } \\
& \text { (1-income tax rate) NPV } \sum\left[\mathrm{kWh}_{\mathrm{RW}} \times\left(\mathrm{U}_{\mathrm{t}} \text { tility total production cost/kWh }- \text { Market price } \mathrm{in}_{\mathrm{ij}}\right.\right. \\
& \mathrm{t}=1 \quad \mathrm{j}=1 \quad+\text { rate-design adjustments } \mathrm{t}_{\mathrm{j}} \mathrm{j} \text {, }
\end{aligned}
$$

where NPV is the net present value calculated at the utility's return on equity for the $t$ years through year $T$. Determining $T$ is a difficult policy decision because the annual values calculated with Eqn. 1 may be positive for a few years and then turn negative. The subscript $j$ refers to one of the $\mathrm{N}$ customer classes, and the term $\mathrm{kWh}_{\mathrm{RWtj}}$ is the annual energy loss that the utility experiences because of RW.

Equation 1 has two terms. The first term represents the amount of money lost because the utility now collects from wheeling customers only the market price ${ }^{*}$ for electricity, whereas before it collected the embedded cost (fixed plus variable costs) of production and purchased power. The estimates of average utility production cost and market price must be consistent

*In practice, the utility may not have to discount the price all the way to the wholesale-market price. 
with each other. Specifically, all prices and costs must be measured at the same level in the T\&D system (e.g., at the generator busbar) to consistently reflect electrical losses in the T\&D system, and they must include only comparable costs (e.g., generation only with T\&D costs excluded). Also, both annual averages must be weighted by electricity consumption, not by time. Because MC and wholesale price generally increase with demand, consumption-weighted values are higher by roughly 5 to $10 \%$ than time-weighted values.

The second term represents any losses associated with rate design (i.e., nonproduction costs that are not fully reflected in T\&D wheeling rates). For example, this term could include the annual costs of social programs that are assigned to generation and are therefore not reflected in $T \& D$ rates.

Equation 1 involves a summation over the $\mathrm{N}$ rate classes. The losses associated with production costs and market prices will differ across rate classes based on the different load shapes and T\&D losses for each class. The losses associated with rate design will also differ across rate classes because the tariff designs may differ in their allocations of generation vs other costs to different classes.

Consider, as a simple example, two customer classes. The residential class has a load factor of $50 \%$, and the commercial/industrial (C/I) class has a load factor of $65 \%$. Ignoring the differences in load shape between the two classes would lead to a $33 \%$ overestimate of SC if only the residential class was at risk and to a $31 \%$ underestimate of SC if only the $\mathrm{C} / \mathrm{I}$ class was at risk. These errors occur because the cost per kilowatt-hour to serve the residential class is higher than that for the $\mathrm{C} / \mathrm{I}$ class and this difference is not reflected in rates that are averaged across all retail classes. These substantial errors emphasize the importance of calculating costs and prices for the particular customers that are eligible for RW.

The term ( 1 - income tax rate) shows that any losses experienced by a private firm are offset in part by reduced federal and state income-tax payments. For example, if a utility's combined federal-state income tax rate is $36 \%$, its shareholders will face only $64 \%$ of any losses associated with retail wheeling. Taxpayers will bear the remainder through lower tax receipts.

Implementation of this approach is simple. One first estimates the total production costs for each applicable rate class and then estimates, in a consistent fashion, the market price that each class would face. By consistent, we mean an approach that reflects the voltage levels, T\&D losses, and load shapes of each class in calculating the utility's costs to serve that load and in calculating the market price to serve that load. These calculations require only a rudimentary knowledge of the utility's production costs and the wholesale power market. 
Second, one estimates the effects of rate design on lost revenues. This process requires an understanding of utility accounting and ratemaking but not of wholesale markets or production costs.

\section{LOSE-SALE METHOD}

The basic formula for calculating SC with the LS option is:

$$
\begin{aligned}
& \text { T N } \\
& \text { (1-income tax rate) } \mathrm{NPV} \sum\left[\mathrm{kWh} \mathrm{RWt}_{\mathrm{tj}} \times(\mathrm{Utility} \text { total production cost } / \mathrm{kWh}-\mathrm{Utility} \mathrm{MC})_{\mathrm{tj}}\right. \\
& \mathrm{t}=\mathrm{l} \quad \mathrm{j}=1-\operatorname{Max}\left\{0, \Delta \mathrm{kWh}_{\mathrm{WStj}} \times\left(\text { Market price }_{\text {out }}-\text { Utility } \mathrm{MC}\right)_{\mathrm{tj}}\right\} \\
& + \text { rate-design adjustments }{ }_{t \mathrm{j}} \text {, }
\end{aligned}
$$

where $\Delta \mathrm{kWh}$ WS is the change in wholesale sales made possible by the energy freed up by the retail-wheeling loss and $\mathrm{MC}$ is marginal production cost in $\phi / \mathrm{kWh}$.

The first term represents the revenue loss to the utility associated with the loss of sales from RW customers. This term differs from that in the KS formula. In Eqn. 1, this term depends on the market price of power; in Eqn. 2, it depends on the utility's marginal costs of serving the departing customers.

The second term represents the possible revenue gain to the utility if it can profitably resell some of the lost sales on the wholesale market. This term is calculated as the maximum of zero (to be sure that the utility does not resell at a loss) and the product of the amount of resale $(\Delta \mathrm{kWh}$ WS $)$ and the difference between the price that the utility would receive for this power on the wholesale market and the utility $\mathrm{MC}$ to produce this amount of electricity.

The amount of resale is less than or equal to the amount of $R W$ loss $\left(k W h_{R W}\right)$. We know of no simple way to calculate the fraction of the RW loss that can be resold. In practice, it is a complicated function of transmission constraints, unused generating capacity, and the relationship between the utility's $\mathrm{MC}$ and wholesale market price at different times during the year. Also, the market price in this second term may differ from that in the KS calculation. Because of transmission losses and congestion, the wholesale price that the utility receives (Market price ${ }_{\text {out }}$ ) may be different from the price that it pays when it buys on the wholesale market (Market price ${ }_{\text {in }}$ ); we call this difference $\Delta$ WS-price.

Figure 2 shows how the ratio of change in wholesale sales to retail-wheeling losses $\left(\Delta \mathrm{kWh}_{\mathrm{WS}} / \mathrm{kWh}_{\mathrm{RW}}\right)$ varies with wholesale market prices when transmission is unconstrained. ${ }^{*}$

"The difference between the utility's wholesale purchase and sale prices is $0.2 \phi / \mathrm{kWh}$ for the example shown in Fig. 2. If the difference was zero, the ratio of change in wholesale sales to RW loss would be 1.0 across the entire range of wholesale prices. 
At very low market prices, the utility will purchase on the spot market as much energy as it can until its $\mathrm{MC}$ is no longer above the spot price. (Recall the discussion of Fig. 1 in Chapter 2.) The opposite occurs at very high market prices. Here the utility will sell as much energy as it can until its MC is no longer below the spot price. Between these two extremes, whether the utility buys or sells differs between the base and retail-wheeling cases because of differences in the marginal production costs for the two cases. Because the MC is lower in the RW case, the utility begins to sell at lower wholesale prices than in the base case.

\section{INCREASE IN WHOLESALE SALES/RETAIL WHEELING LOSS}

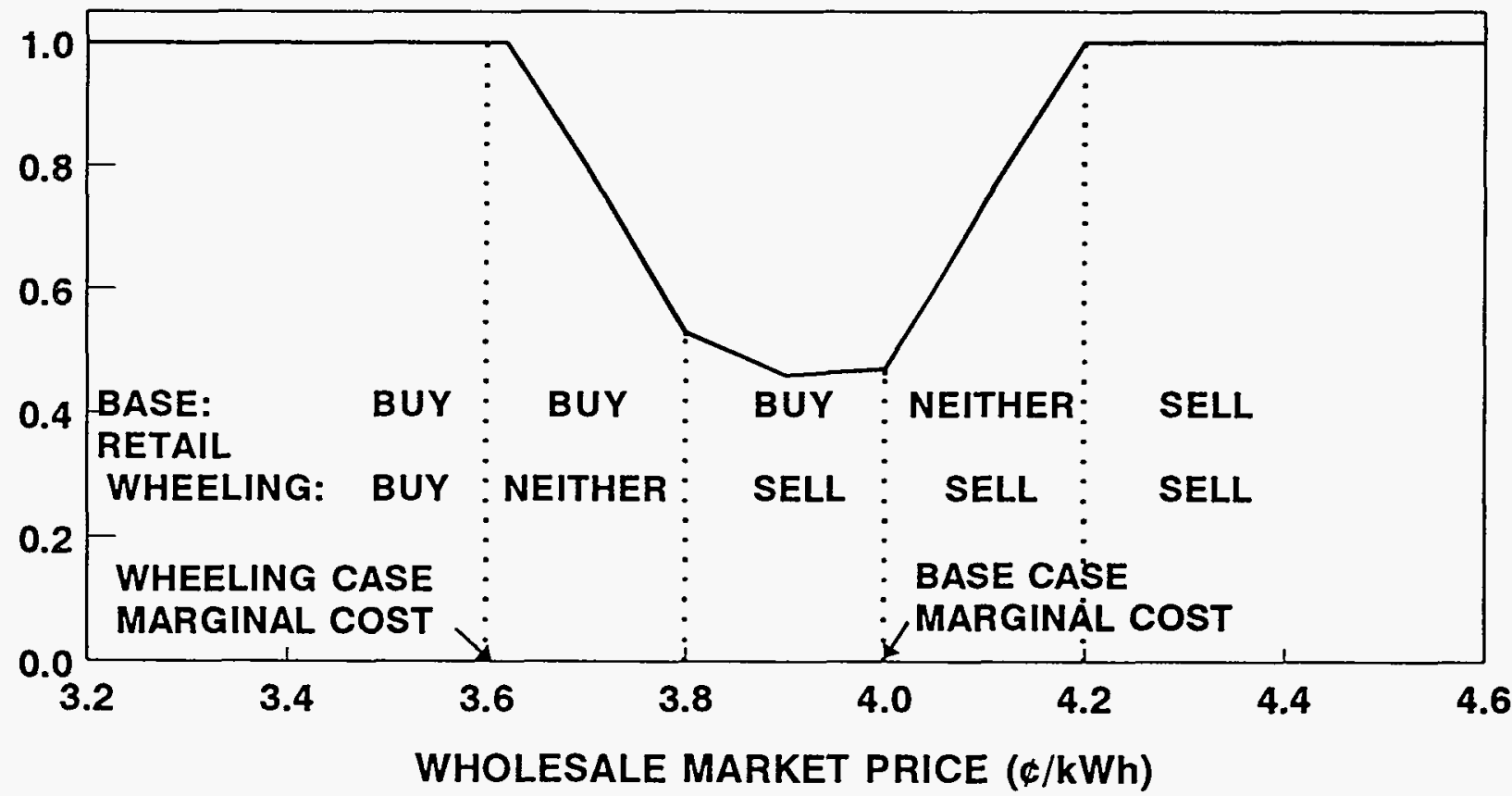

Fig. 2. Ratio of increase in wholesale sales (retail-wheeling case minus base case) to retail-wheeling loss as a function of wholesale electricity price. In this example, transmission is unconstrained, and the difference between the purchase and sale prices for wholesale power is $0.2 \phi / \mathrm{kWh}$.

Imposing a transmission constraint has no effect when wholesale prices are near the utility's MC. At high and low market prices, however, the transmission constraint is binding. At the extreme values, where the utility is either buying or selling all it can, the transmission constraint limits this amount to be the same in the base and RW cases, yielding a ratio of zero. Under these conditions, RW has no effect on wholesale transactions.

The third term in Eqn. 2 is identical to the second term discussed above for the KS option.

In the special case where $k W h_{\mathrm{RW}}$ (sales lost to wheeling) equals $\Delta \mathrm{kWh}_{\mathrm{WS}}$ (net change in wholesale sales) and Market price ${ }_{\text {in }}$ equals Market price $_{\text {out }}$, the KS and LS formulas are the 
same (compare Eqns. 1 and 2). Given the hour-to-hour variations in utility $\mathrm{MC}$, spot prices, and transmission constraints, plus the mismatches between rate structures and these time-varying costs, these conditions are unlikely to occur. Thus, the KS and LS options are distinct.

The complications associated with calculating LS-SC amounts argue for further simplification. Consider the following progression of formulae to calculate SC if the utility loses the sale (to simplify the presentation, we drop the NPV, summation, adjustment for income taxes, and the third term in Eqn. 2):

$$
\mathrm{kWh}_{\mathrm{RW}} \times(\text { Utility production cost } / \mathrm{kWh}-\text { Utility variable cost } / \mathrm{kWh}) .
$$

This formula involves two simplifications. First, the possibility of reselling any of the sales lost to retail wheeling is ignored. Thus, this method will overestimate the amount of SC for the LS option. Second, in place of the utility's MC, we substitute its average variable production cost because it is easier to compute the average variable cost than the average MC. Because average variable cost is less than $\mathrm{MC}$, this assumption further overestimates $\mathrm{SC}$.

We can improve on Eqn. 3 by recognizing that the utility can resell some or all of the electricity lost to retail wheeling:

$\mathrm{kWh}_{\mathrm{RW}} \times(\mathrm{Utility}$ production cost $/ \mathrm{kWh}-$ Utility variable cost $/ \mathrm{kWh})$

$-\operatorname{Max}\left\{0, \mathrm{kWh} \mathrm{RW}_{\mathrm{RW}} \times\left(\right.\right.$ Market price $_{\text {out }}$ - Utility variable cost $\left.\left./ \mathrm{kWh}\right)\right\}$.

This formula assumes that all such losses can be resold on the wholesale market. Thus, Eqn. 4 will yield a smaller estimate of SC than will Eqn. 3 .

We could further improve Eqn. 4 by substituting $\Delta \mathrm{kWh}_{\mathrm{WS}}$ for $k \mathrm{kh}_{\mathrm{RW}}$ if we had a method for estimating the fraction of RW sales lost that is resold on the wholesale market. Doing so would yield an estimate of SC larger than that calculated with Eqn. 4 because the amount of resale will always be less than or equal to the amount of retail-wheeling loss. Unfortunately, we were not able to identify any consistent patterns that would lead to a simple algorithm for defining this ratio.

In addition, we could substitute various estimates of the utility's MC for variable cost. These estimates could be based on the pre-RW dispatch of the utility's power plants and powerpurchase contracts, on the post-RW dispatch, or on some average of the two. The pre-RW estimate is too high, and the post-RW estimate is too low, but it is not clear how to average the two values to develop an accurate estimate of the MC of serving the RW load that the utility loses. Using the pre-RW estimate of MC yields a value of SC that is lower than the amount calculated with variable cost (because $\mathrm{MC}$ is always higher than variable cost). 
In summary, Eqn. 3 substantially overestimates the actual LS amount of SC. At the other end of the spectrum, TD-LS estimates that assume 100\% resale and pre-RW MC substantially underestimate the correct value. Although the results of Eqn. 4 are often closest to the actual $\mathrm{SC}$ amounts, the differences between various TD methods and the correct answer vary enormously from case to case. 


\section{BOTTOM-UP METHODS}

Bottom-up methods treat individually each generating unit, power-purchase contract, and balance-sheet item to calculate the amount of money a utility might lose because of RW. Here we present ORFIN, an example of a BU method. This chapter also describes the base-case utility we used to calculate TD and BU estimates of SC.

\section{THE OAK RIDGE FINANCIAL MODEL}

ORFIN is a simplified version of a utility integrated planning model. It includes a production-costing module; utility financial statements (income statement, balance sheet, and cash-flow statement); and a rate-design module (functionalization, classification, and allocation of costs to customer classes).

Analysis of SC costs requires two ORFIN runs. The first run is a base case with no RW. Generally, we ran the no-wheeling case using annual rate cases with a future test year to ensure that the utility earns its authorized return on equity for each year of the analysis period; assuming that the utility earned more or less than its authorized return would affect SC estimates. The second run includes RW with the user specifying the timing and amount of wheeling that occurs year by year. The RW case has retail electricity prices set equal to those in the reference case. Differences in annual earnings between the base and RW cases are the model's estimates of SC losses that the utility's shareholders would experience. Keeping prices fixed between the base and retail-wheeling cases ensures that none of the SC costs are borne by retail customers; all are borne by utility shareholders.

ORFIN allows for a variety of user inputs to test the effects of many factors on production costs, assets, incomes, and losses (Table 1). The user provides information on the initial state of the utility (e.g., as of 1995). These initial conditions include information on the utility's power plants and long-term power-purchase contracts; nomproduction operations and maintenance (O\&M) costs (which include transmission, distribution, and customer service); balance sheet; and customer classes. The user also specifies the values of fuel prices for the initial year and their escalation with time; these prices affect the wholesale-market prices and the utility's variable production costs. 


\section{Table 1. Key inputs to ORFIN}

\section{Nongeneration operating costs}

Transmission, distribution, customer service, and administrative and general (A\&G)

O\&M costs (\$/year), social program costs (\$/year), and O\&M cost escalation (\%/year)

Nongeneration capital costs

Transmission, distribution, and general capital costs $(\$ /$ year, $\$ /$ customer, $\$ / \Delta \mathrm{kW})$

\section{Power-purchase contracts}

Capacity (MW), offline date (year), forced and planned outage rates (\%), fixed costs $(\$ / \mathrm{kW}$-year), and variable costs $(\phi / \mathrm{kWh})$

\section{Utility-owned generating units}

Capacity (MW), initial cost ( $\$ / \mathrm{kW})$, start and offline dates (year), tax and book depreciation lives (years), forced and planned outage rates (\%), fixed O\&M cost $(\$ / \mathrm{kW}$ year), variable O\&M cost $(\phi / \mathrm{kWh}), \mathrm{O} \& \mathrm{M}$ escalation rate (\%/year), heat rate $(\mathrm{Btu} / \mathrm{kWh})$, fuel type, and fuel prices ( $\$ \mathrm{MBtu})$ by year

\section{Wholesale-market prices}

Prices $(\phi / \mathrm{kWh})$ by time period (\% of year), escalation rates (\%/year), difference between wholesale purchase and sale price $(\phi / \mathrm{kWh})$, and transmission capacity (MW)

\section{Customers}

By class: number of customers, consumption ( $\mathrm{kWh} /$ customer-month), load factor, growth rates (\%/year) in number of customers and in per-customer consumption, and T\&D energy and demand losses

\section{Retail wheeling}

Percentage of customers from each class that wheel by year, percentage of A\&G costs paid by wheelers, and ancillary-service cost adder $(\phi / \mathrm{kWh})$

\section{Finances}

Long-term bonds and common equity ( $\%$ of total capitalization and return in $\% / y e a r)$, inflation rate (\%/year), federal/state income tax rate (\%), revenue-sensitive tax rate $(\%)$, property tax rate (\%), frequency and type (historic vs future test year) of rate cases, and regulatory assets

Information on production includes, for each generating unit, capacity (MW), construction cost, tax and book depreciation lives, year of initial operation, plant operating lifetime, forced and maintenance outage rates, fixed and variable O\&M costs, heat rate, and fuel type.

ORFIN includes three customer classes, residential, C/I, and RW. Initial conditions for the first two classes include the number of customers, annual electricity use per customer, load factor, T\&D losses, and annual growth in the number of customers and in usage per customer. User inputs for the wheeling class include the year wheeling begins, the fractions of residential and $\mathrm{C} / \mathrm{I}$ customers that switch to wheeling each year, the fraction of general plant A\&G costs 
paid by wheelers, and any charges for ancillary services that the utility includes in its wheeling tariff.

ORFIN conducts rate cases according to a schedule set by the user. These rate cases can use either a historical or a future test year. In either case, ORFIN first functionalizes all costs as production, transmission, distribution, or general (Chamberlin 1981). These costs are then classified as energy, demand, or customer. Finally, the costs are allocated among the three customer classes. The residential class faces only energy and customer charges $(\phi / \mathrm{kWh}$ and $\$ /$ month, respectively). The $\mathrm{C} / \mathrm{I}$ and wheeling classes also face a demand charge in $\$ / \mathrm{kW}$ month. The charges to wheeling customers exclude production costs. The user specifies how fixed costs are classified, which affects the energy, demand, and customer charges to each class.

The Dispatch module uses data for each year to calculate the generation, contract purchases, and wholesale (spot) purchases and sales for the utility. The model allows for six existing generating units, two long-term power-purchase contracts, one new resource (a utilityowned plant or a contract), and new plants that are added in small increments each year to just meet the utility's reserve requirements. The model matches production and loads for a peak period (that includes no planned outages) and an off-peak period [where plants are derated so that their annual availability matches $(1$ - forced outage rate - planned outage rate)]. These production-cost results are then used by the financial portions of ORFIN to calculate O\&M costs.

First, Dispatch calculates load-duration curves for the peak and off-peak seasons. Next, the ten plants (including contracts) are sorted in order of their variable costs. Any must-run plants can be given a zero bid price for dispatching purposes.

The load-duration curve is defined as the percentage of the season a given power level is met or exceeded. ORFIN calculates an equivalent load-duration curve for each plant that modifies the original load-duration curve to reflect the probability that plants lower in the dispatch order are unavailable because of forced outages. For example, assume the plants all have a $10 \%$ forced outage rate. The second plant will see a demand curve with the first plant subtracted out $90 \%$ of the time and the full demand curve $10 \%$ of the time. The third plant will see the demand curve minus both lower-cost plants $81 \%$ of the time, minus only the first plant $9 \%$, minus only the second plant $9 \%$, and the full demand curve $1 \%$ of the time. These calculations are built up for each plant from zero output up to the utility's maximum demand. The details of startup costs and ramp time, part-load heat rates, and other complicating factors are ignored in these calculations (Wood and Wollenberg 1984).

The percentage of the season a plant operates is calculated for up to 22 power levels. Additional points could be used to increase accuracy, but only at the expense of computation 
speed and file size. ${ }^{*}$ These 22 points (for each season) are sorted by increasing power level before calculating the equivalent load-duration curve for each plant.

After the operating times for all plants are calculated for the year, ORFIN checks to see if it is economical to sell excess power on the spot market or to displace some of its production with spot purchases. The user inputs four wholesale power prices for different fractions of the year. ORFIN compares the variable cost for each plant with the spot purchase and sale prices for each period. If the plant's variable cost is lower than the current spot sale price and the plant has excess capacity, then the plant will sell into the market. If its variable cost is higher than the spot purchase price and it is producing at that time, then the plant is backed off and wholesale power is purchased instead. ORFIN compares each possible transaction with the input transmission-capacity constraint and limits wholesale sales and purchases accordingly. ${ }^{\#}$

Lack of generating capacity and/or transmission constraints may limit the ability of the utility to meet all its customers' electrical requirements. This unmet (emergency) demand is purchased on the wholesale market at the highest wholesale-power price.

ORFIN's income statement shows the results of the utility's operations for a calendar year (Hirst and Hadley 1994). The income statement has three parts: revenues, expenses, and income. Income is the difference between revenues and expenses. Revenues are the product of electricity sales and electricity price, summed over the three customer classes. Operating expenses include production costs, nonproduction (transmission, distribution, and customer service) costs, book depreciation, income and other taxes, and interest payments. Production expenses include fuel and O\&M costs for the utility's power plants, power-purchase contract costs, and purchases and sales on the spot market. Net income is the return to utility shareholders.

ORFIN's balance sheet shows the utility's assets, liabilities, and shareholder equity as of the end of a calendar year. By definition, assets equal the sum of liabilities plus equity. Gross assets, the original undepreciated costs of investments, are split into four categories: production, transmission, distribution, and general. Accumulated book depreciation is the sum of the annual amounts of book depreciation. Net plant is the difference between gross plant and accumulated depreciation. Assets also include construction work in progress, regulatory assets, and miscellaneous items. Together, these items add up to total assets.

*It takes less than one minute to run reference and retail-wheeling cases with 11 years of production costing with a Pentium- 90 personal computer.

\#ORFIN allows the user to specify different transmission constraints for incoming (purchase) and outgoing (sale) transactions. The model also allows one to credit or debit the retail-wheeling capacity against these transmission constraints. We did not use these model capabilities for the current analysis because, in our view, they add an unnecessary complication. 
The second half of the balance sheet shows capitalization, which in ORFIN is primarily bonds and stocks. Liabilities include long-term debt and accumulated deferred income-tax payments. Shareholder equity is the sum of common stock plus retained earnings.

\section{BASE-CASE UTILITY}

We used historical data from the Energy Information Administration (EIA 1995a) to create a utility suitable for analysis. We did not create a utility that is "typical" of the large U.S. investor-owned utilities; rather we created a hypothetical utility with a substantial amount of stranded commitment. We developed a base case and a retail-wheeling case for this utility for analysis from 1995 through 2005.

\section{$\underline{\text { Base Case }}$}

In 1995 , the initial year of simulation, the utility's retail sales totaled $22,700 \mathrm{GWh}$, nearly one-third to the residential class and the remainder to the $\mathrm{C} / \mathrm{I}$ class. The utility's peak demand was $4610 \mathrm{MW}$, yielding an overall load factor of $56 \%$. With residential loads growing at $0.8 \%$ /year and $\mathrm{C} / \mathrm{I}$ loads growing at $1.2 \%$ /year, total load grows at $1.1 \%$ /year (Table 2 ), the same as that projected by EIA (1995b).

The utility owns generating units with a combined eapacity rating of $4210 \mathrm{MW}$. In addition, the utility has two long-term power-purchase contracts that provide another $1600 \mathrm{MW}$ of capacity. Thus, in 1995 the utility had a reserve margin of $26 \%$. The utility's capacity factor of $45 \%$ (ratio of generation to potential generation) was slightly less than that of the nation's utilities overall (EIA 1995c). The utility's generation operating costs ranged from 1.0 to $5.5 \notin / \mathrm{kWh}$ in 1995 . The utility can buy and sell on the spot market up to a maximum of 1000 MW (which represents the maximum capacity in either direction of the transmission system in that region). ${ }^{*}$ The 1995 spot prices range from 2.0 to $9.0 \% / \mathrm{kWh}$, depending on the time of year. ${ }^{\#}$ Real wholesale prices remain constant from 1995 through 2000 and then increase at 3\%/year thereafter. Weighted by consumption, the average spot price in 1995 was $3.8 \notin / \mathrm{kWh}$, essentially the same as the utility's average MC (Fig. 3). Because spot prices are sometimes above and sometimes below the utility's marginal cost of generation, the utility both buys and sells on the spot market. In 1995, the utility bought $3100 \mathrm{GWh}$ and sold $1500 \mathrm{GWh}$.

With an average retail rate of $8.25 \notin / \mathrm{kWh}$, the utility's total revenues in 1995 were $\$ 1.75$ billion. Net income was $\$ 148$ million, which yielded a return on equity of $11.5 \%$ (close to the

*Transmission constraints limit wholesale transactions in many parts of the country (e.g., between Georgia and Florida and between Northern and Southern California).

\#The marginal energy cost in Texas ranges from 0.5 to $9 \notin / \mathrm{kWh}$ (Matlock 1995) and in California from 1 to $10 \notin / \mathrm{kWh}$ (White 1995 ). 
national average of $11.3 \%$; EIA 1995a). The utility's assets totaled $\$ 3.96$ billion that year, of which $\$ 1.26$ billion was in shareholder equity.

The utility's average price of $8.25 \% / \mathrm{kWh}$ included $2.85 \% / \mathrm{kWh}$ for fixed production costs, $2.15 \phi / \mathrm{kWh}$ for variable production costs, and $3.25 \% / \mathrm{kWh}$ for transmission, distribution, and other costs (Fig. 3). This retail price was 19\% higher than the average price for U.S. utilities (EIA 1995c).

With inflation at 3\%/year, modest load growth, no increases in fuel prices, no new generating units coming online, and no investment in existing generating units, the utility's assets decline from $\$ 3.96$ billion in 1995 to $\$ 3.26$ billion in 2005 . In addition, all production costs, both O\&M and fuel, remain constant in real dollars during the analysis period. As a consequence, real retail rates decline from $8.25 \phi / \mathrm{kWh}$ in 1995 to $6.70 \phi / \mathrm{kWh}$ in 2005 ; EIA (1995b) projects essentially no change in real electricity prices to 2010. (All real dollar figures are in 1995 dollars.)

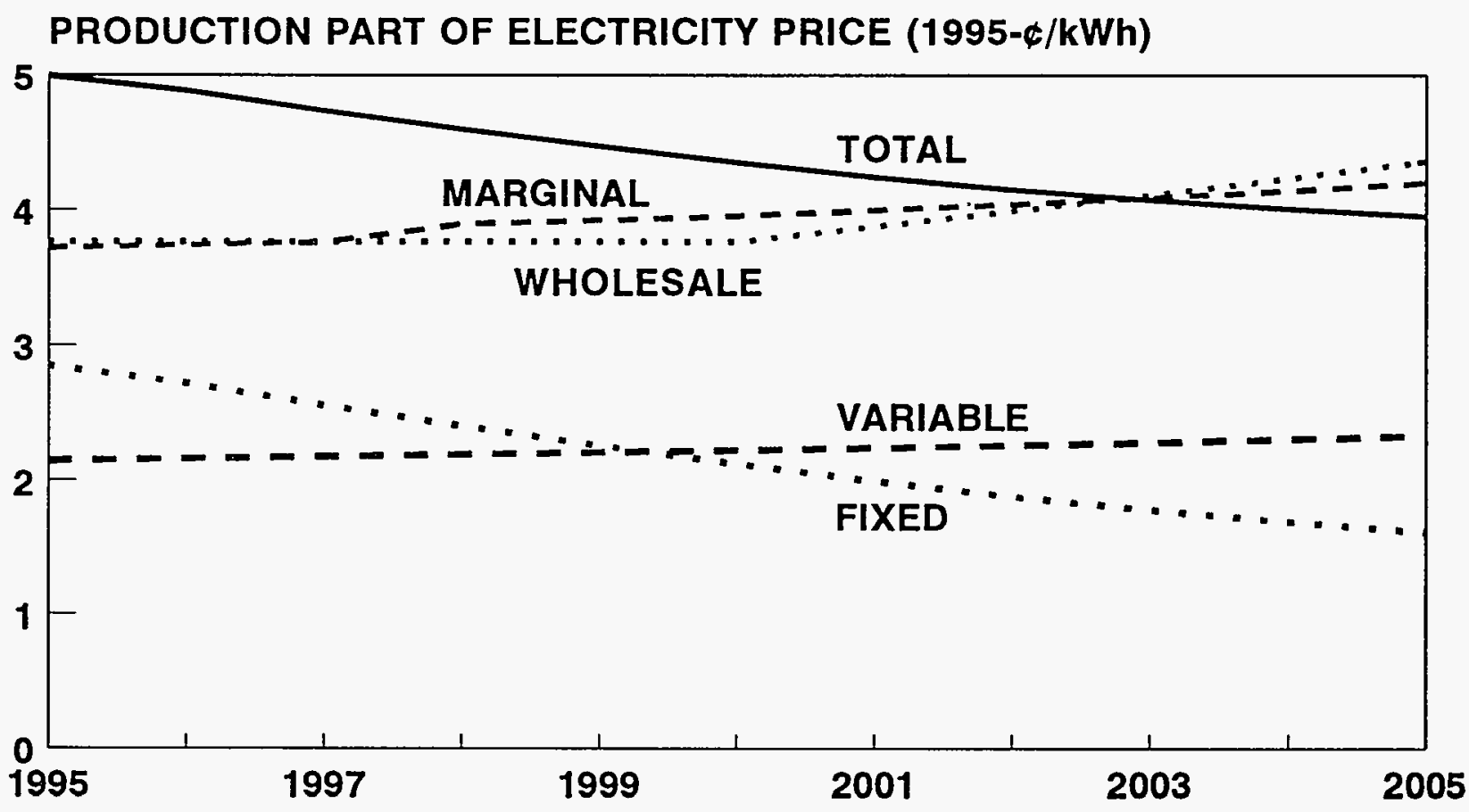

Fig. 3. The utility's fixed, variable, total, and marginal production costs plus spot prices for the base case from 1995 to 2005 . Fixed costs decline because of inflation, load growth, and the lack of investment in generation. Variable and marginal costs increase because of load growth. Wholesale prices increase at 3\%/year after 2000. 
Table 2. Summary information from ORFIN for the base case

\begin{tabular}{|c|c|c|c|c|c|c|c|}
\hline & 1995 & 1996 & 1997 & 1998 & 1999 & 2000 & 2005 \\
\hline \multicolumn{8}{|l|}{ ANNUAL SUMMARY } \\
\hline Retail sales (GWh) at busbar & 22,713 & 22,956 & 23,203 & 23,452 & 23,704 & 23,959 & 25,276 \\
\hline Wholesale (spot) sales (GWh) & 1,639 & 1,573 & 1,509 & 1,447 & 1,386 & 1,326 & 1,883 \\
\hline Wholesale (spot) purchases (GWh) & $-3,143$ & $-3,266$ & $-3,390$ & $-3,521$ & $-3,655$ & $-3,787$ & $-4,446$ \\
\hline Net wholesale GWh & $-1,505$ & $-1,692$ & $-1,882$ & $-2,074$ & $-2,269$ & $-2,461$ & $-2,563$ \\
\hline Retail wheeling & 0 & 0 & 0 & 0 & 0 & 0 & 0 \\
\hline \multicolumn{8}{|l|}{ Peak demand at busbar (MW) } \\
\hline Retail & 4,608 & 4,657 & 4,706 & 4,755 & 4,805 & 4,855 & 5,116 \\
\hline Wholesale sales & 665 & 641 & 618 & 595 & 572 & 550 & 827 \\
\hline Wholesale purchases & 974 & 980 & 985 & 991 & 997 & 1,000 & 1,000 \\
\hline Retail wheeling & 0 & 0 & 0 & 0 & 0 & 0 & 0 \\
\hline \multicolumn{8}{|l|}{ Costs and prices (1995 \&/kWh) } \\
\hline Average retail price & 8.25 & 8.04 & 7.84 & 7.65 & 7.47 & 7.3 & 6.7 \\
\hline \multicolumn{8}{|l|}{ Average production costs } \\
\hline Fixed & 2.85 & 2.72 & 2.56 & 2.41 & 2.26 & 2.13 & 1.62 \\
\hline Variable & 2.15 & 2.16 & 2.18 & 2.19 & 2.21 & 2.23 & 2.33 \\
\hline Total & 5 & 4.88 & 4.74 & 4.6 & 4.47 & 4.35 & 3.95 \\
\hline Average marginal cost of generation & 3.72 & 3.74 & 3.76 & 3.89 & 3.92 & 3.95 & 4.2 \\
\hline Wholesale price to meet demand & 3.76 & 3.76 & 3.76 & 3.76 & 3.76 & 3.76 & 4.36 \\
\hline Return on equity (\%) & 11.5 & 11.5 & 11.5 & 11.5 & 11.5 & 11.5 & 11.5 \\
\hline \multicolumn{8}{|l|}{ INCOME STATEMENT (million \$) } \\
\hline Revenues & 1,745 & 1,771 & 1,797 & 1,826 & 1,856 & 1,889 & 2,120 \\
\hline \multicolumn{8}{|l|}{ Expenses } \\
\hline Fuel & 311 & 321 & 331 & 342 & 353 & 365 & 474 \\
\hline Power-purchase contracts & 184 & 189 & 193 & 198 & 203 & 208 & 236 \\
\hline Spot purchases & 74 & 80 & 86 & 93 & 100 & 108 & 180 \\
\hline Spot sales & -86 & -85 & -83 & -82 & -81 & -79 & -146 \\
\hline Purchased power, total & 173 & 184 & 196 & 209 & 223 & 237 & 270 \\
\hline O\&M, fixed + variable & 247 & 255 & 263 & 271 & 279 & 288 & 354 \\
\hline Production expenses, total & 730 & 760 & 790 & 822 & 855 & 890 & 1,098 \\
\hline Nonproduction expenses & 237 & 244 & 250 & 257 & 264 & 271 & 309 \\
\hline Book depreciation & 150 & 151 & 152 & 153 & 154 & 155 & 163 \\
\hline Depreciation of regulatory asset & 8 & 8 & 8 & 8 & 8 & 8 & 8 \\
\hline Rēvenue sensitive taxes & 122 & 124 & 126 & 128 & 130 & 132 & 148 \\
\hline Property taxes & 77 & 77 & 75 & 74 & 73 & 71 & 66 \\
\hline Federal income taxes, current & 71 & 68 & 65 & 62 & 59 & 57 & 96 \\
\hline Federal income taxes, deferred & 12 & 12 & 12 & 12 & 12 & 12 & -34 \\
\hline Expenses, total & 1,408 & 1,443 & 1,478 & 1,516 & 1,555 & 1,596 & 1,854 \\
\hline Interest expense & 189 & 186 & 182 & 178 & 175 & 171 & 156 \\
\hline Net income & 148 & 142 & 137 & 132 & 126 & 121 & 110 \\
\hline \multicolumn{8}{|l|}{ BALANCE SHEET (million \$) } \\
\hline Assets & 3,963 & 3,885 & 3,809 & 3,734 & 3,660 & 3,589 & 3,257 \\
\hline Equity & 1,260 & 1,213 & 1,167 & 1,121 & 1,077 & 1,033 & 962 \\
\hline
\end{tabular}




\section{Retail-Wheeling Case}

We assume that RW begins in 1996 with $10 \%$ of both the residential and $\mathrm{C} / \mathrm{I}$ classes eligible for wheeling that year and that these percentages remain constant through 2005. (In reality, the timing and amount of RW depends on the utility's rates, wholesale prices, and customer price elasticity.) We also assume that retail and wheeling rates are the same in the retail-wheeling case as they are in the base case. Thus, for purposes of this analysis, all the costs of RW fall on utility shareholders.

Table 3 shows the effects of wheeling on the utility; the numbers in Table 3 are the differences between the base-case and retail-wheeling-case values. The reduction in sales to the utility's retail customers is offset in part by increases in spot sales and decreases in spot purchases. Roughly speaking, for every kilowatt-hour reduction in retail sales, the utility reduces its net spot purchases by $0.8 \mathrm{kWh}$. Because of $\mathrm{RW}$, the fixed-cost component of generating costs increases, for example from 2.13 to $2.36 \not / \mathrm{kWh}$ in 2000 . These increases are offset in part by reductions in the variable-cost component of generating costs, which drops from 2.23 to $2.07 \phi / \mathrm{kWh}$. The net effect of RW is a slight increase in production costs (e.g., $0.08 \notin / \mathrm{kWh}$ in 2000).

The utility’s earnings loss decreases from year to year, from $\$ 25$ million in 1995 to $\$ 19.2$ million in 2000 to $-\$ 0.1$ million in 2005 (Table 4 and Fig. 4). This reduction is a consequence of the decline over time in the fixed-cost component of electricity costs and the increase in wholesale prices after 2000 (Fig. 3) and is consistent with other estimates of the temporal pattern of losses (Matlock 1995). This temporal pattern illustrates well the difficulty in deciding how many years to include in a stranded-commitment analysis. On an NPV basis, with the authorized return on equity of $11.5 \%$, the earnings loss is $\$ 100$ million, which represents $8.2 \%$ of utility equity as of 1995. Our utility's potential loss is small compared to that estimated for many U.S. utilities because we assume that only $10 \%$ of the utility's load is at risk.

If the utility were to retain the loads of these RW customers, its losses would be lower. On a NPV basis, the KS loss would be $\$ 82$ million, $18 \%$ less than the LS amount. Thus, in this particular case, the utility should, if possible, retain the potentially lost customers and charge them market-based rates. Even if $\Delta$ WS-price equaled zero and transmission capacity was infinite, the KS loss would still be less than the LS loss ( $\$ 80$ million vs $\$ 88$ million). 
Table 3. Differences between base case and retail-wheeling case

\begin{tabular}{|c|c|c|c|c|c|c|}
\hline & 1996 & 1997 & 1998 & 1999 & 2000 & 2005 \\
\hline ANNUAL SUMMARY & \multicolumn{6}{|c|}{ (Retail-wheeling results minus base-case results) } \\
\hline Retail sales (GWh) at busbar & $-2,296$ & $-2,320$ & $-2,345$ & $-2,370$ & $-2,396$ & $-2,528$ \\
\hline Wholesale (spot) sales (GWh) & 617 & 613 & 621 & 624 & 623 & 550 \\
\hline Wholesale (spot) purchases (GWh) & 1,218 & 1,246 & 1,256 & 1,267 & 1,270 & 1,284 \\
\hline Net wholesale GWh & 1,836 & 1,858 & 1,877 & 1,891 & 1,893 & 1,834 \\
\hline Retail wheeling & 2,296 & 2,320 & 2,345 & 2,370 & 2,396 & 2,528 \\
\hline \multicolumn{7}{|l|}{ Peak demand at busbar (MW) } \\
\hline Retail & -466 & -471 & -475 & -480 & -486 & -512 \\
\hline Wholesale sales & 232 & 227 & 230 & 230 & 230 & 173 \\
\hline Wholesale purchases & -154 & -140 & -126 & -113 & -96 & -25 \\
\hline Retail wheeling & 466 & 471 & 475 & 480 & 486 & 512 \\
\hline \multicolumn{7}{|l|}{ Costs and prices (1995 ф/kWh) } \\
\hline Average retail price & 0 & 0 & 0 & 0 & 0 & 0 \\
\hline Average production costs & 0 & 0 & 0 & 0 & 0 & 0 \\
\hline Fixed & 0.3 & 0.28 & 0.27 & 0.25 & 0.24 & 0.18 \\
\hline Variable & -0.15 & -0.15 & -0.15 & -0.15 & -0.15 & -0.21 \\
\hline Total & 0.15 & 0.13 & 0.12 & 0.1 & 0.08 & -0.03 \\
\hline Average marginal cost of generation & -0.21 & -0.19 & -0.3 & -0.29 & -0.29 & -0.48 \\
\hline Wholesale price to meet demand & 0 & 0 & 0 & 0 & 0 & 0 \\
\hline Return on equity (\%) & -2.04 & -2.01 & -1.95 & -1.87 & -1.77 & 0.01 \\
\hline \multicolumn{7}{|c|}{ INCOME STATEMENT (million \$) } \\
\hline Revenues & -132 & -134 & -135 & -137 & -139 & -155 \\
\hline \multicolumn{7}{|l|}{ Expenses } \\
\hline Fuel & -6 & -6 & -7 & -7 & -8 & -18 \\
\hline Power-purchase contracts & -7 & -8 & -8 & -8 & -9 & -9 \\
\hline Spot purchases & -33 & -35 & -37 & -39 & -41 & -63 \\
\hline Spot sales & -35 & -36 & -38 & -39 & -40 & -46 \\
\hline Purchased power, total & -75 & -78 & -82 & -86 & -90 & -119 \\
\hline O\&M, fixed + variable & -2 & -2 & -2 & -2 & -2 & -7 \\
\hline Production expenses, total & -84 & -87 & -91 & -95 & -100 & -144 \\
\hline Nonproduction expenses & 0 & 0 & 0 & 0 & 0 & 0 \\
\hline Book depreciation & 0 & 0 & 0 & 0 & 0 & 0 \\
\hline Depreciation of regulatory asset & 0 & 0 & 0 & 0 & 0 & 0 \\
\hline Revenue sensitive taxes & -9 & -9 & -9 & -10 & -10 & -11 \\
\hline Property taxes & 0 & 0 & 0 & 0 & 0 & 0 \\
\hline Federal income taxes, current & -14 & -13 & -13 & -12 & -11 & 0 \\
\hline Federal income taxes, deferred & 0 & 0 & 0 & 0 & 0 & 0 \\
\hline Expenses, total & -107 & -110 & -113 & -117 & -120 & -155 \\
\hline Interest expense & 0 & 0 & 0 & 0 & 0 & 0 \\
\hline Net income & -25 & -24 & -22 & -21 & -19 & 0 \\
\hline \multicolumn{7}{|l|}{ BALANCE SHEET (million \$) } \\
\hline Assets & 0 & 0 & 0 & 0 & 0 & 0 \\
\hline Equity & 0 & 0 & 0 & 0 & 0 & 0 \\
\hline
\end{tabular}


For comparison purposes, ORFIN also calculates SC estimates with the various topdown methods discussed in Chapter 3 (Table 4).

Table 4. Top-down and bottom-up estimates of earnings losses (million \$)

\begin{tabular}{|c|c|c|c|c|c|c|c|}
\hline Method & 1996 & 1997 & 1998 & 1999 & 2000 & 2005 & NPV \\
\hline TD-LS: no resale, $\mathrm{AVC}^{\mathrm{a}}$ & 46.0 & 45.3 & 44.6 & 43.9 & 43.2 & 41.3 & 251.9 \\
\hline TD-LS: $100 \%$ resale, AVC & 24.9 & 23.5 & 22.2 & 20.8 & 19.5 & 1.7 & 102.7 \\
\hline TD-LS: no resale, pre-RW MC & 22.2 & 20.4 & 16.8 & 14.7 & 12.5 & 0.8 & 77.9 \\
\hline TD-LS: $100 \%$ resale, pre-RW MC & 22.2 & 20.4 & 16.8 & 14.7 & 12.5 & 0.8 & 77.9 \\
\hline TD-LS: no resale, average MC & 23.8 & 22.2 & 19.5 & 17.6 & 15.6 & 0.3 & 89.0 \\
\hline TD-LS: $100 \%$ resale, average $\mathrm{MC}$ & 23.8 & 22.0 & 19.2 & 17.2 & 15.1 & 1.7 & 91.3 \\
\hline BU-KS & 21.9 & 20.4 & 18.9 & 17.4 & 15.9 & -2.7 & 82.4 \\
\hline BU-LS & 25.3 & 23.9 & 22.3 & 20.5 & 18.7 & -0.1 & 100.1 \\
\hline
\end{tabular}

${ }^{\mathrm{a}} \mathrm{AVC}=$ average variable cost.

\section{UTILITY EARNINGS LOSS (million \$)}

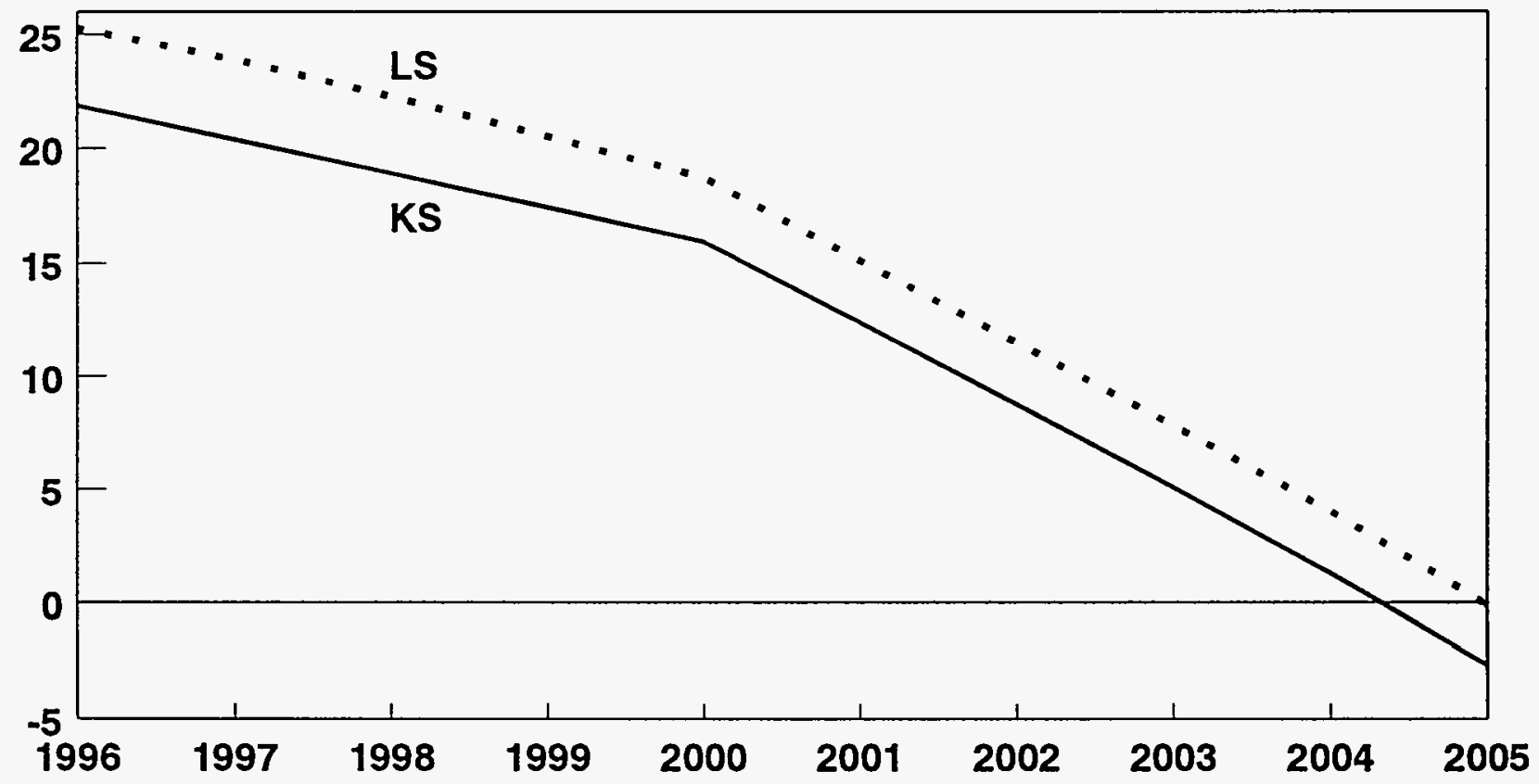

Fig. 4. Annual earnings loss to the ORFIN base-case utility with $10 \%$ of retail customers choosing to wheel. 


\section{FACTORS THAT AFFECT STRANDED-COMMITMENT AMOUNTS}

Stranded commitments (SC) can include four classes of costs (Niagara Mohawk Power Corp. 1994):

- Assets, primarily in expensive power plants and excess capacity

- Liabilities, primarily in power-purchase contracts (including those with qualifying facilities), fuel-supply contracts, and deferred income taxes

- Regulatory assets (whose value is based on regulatory decisions rather than on market forces), including deferred expenses and costs for demand-side management programs that regulators allow utilities to place on their balance sheets

- Public-policy programs, including tax collection, environmental compliance beyond that required by law, demand-side management programs paid for by all customers, special programs for low-income customers, and support for energy research and development. Unlike the other three categories, the costs in this category are current, not sunk.

Baxter (1995) provides additional details on these four cost categories, noting areas of agreement and disagreement among participants in debates about which costs in each category should be considered in calculating stranded commitments.

Here we examine the specific factors that affect SC estimates and classify them as factors that relate to wholesale markets vs accounting factors (Table 5). Calculating SC for the former set of factors requires explicit attention to the interactions between a utility (and its power plants and transmission network) and its surrounding wholesale market (market prices as a function of time and transmission constraints). Factors in the second category require explicit attention to the utility's accounting practices and the mechanics of rate design in that jurisdiction.

\section{THE WHOLESALE MARKET}

The interactions between a utility's generating resources and the wholesale market are crucial to the accurate estimation of SC. Figure 5 shows a hypothetical load-duration curve, utility marginal-cost curve, and wholesale spot prices throughout a particular year. (This figure, based on the ORFIN cases discussed in Chapter 4, is an expanded version of Fig. 1 in 
Chapter 2.) Both utility costs and spot prices are highest when demands are highest (during winter and summer peaks). We purposely drew these curves so that the utility $\mathrm{MC}$ (the variable O\&M plus fuel costs of the most expensive plant in operation at that time) is sometimes above and sometimes below the wholesale spot price.

Table 5. Factors affecting the amount of stranded commitment a utility faces

\begin{tabular}{lcc}
\hline Factor & $\begin{array}{c}\text { Wholesale Accounting } \\
\text { market }\end{array}$ \\
\hline
\end{tabular}

Generation Assets

Capital costs (initial cost, depreciation, taxes, etc.)

Fixed production O\&M

Variable production O\&M

Forced and planned outage rates

\section{Liabilities}

Power-purchase fixed costs

Power-purchase variable costs

Deferred income taxes

Regulatory assets

Public-policy programs

Public-policy programs that are expensed

Other costs (e.g., A\&G expenses) not in wheeling rates

Other factors

Load growth by customer class

Customer-class load factors

Customer-class loss factors

Inflation rate

Income-tax rates

Wholesale-power prices

Difference between wholesale purchase and sale prices

Number of customers that choose retail wheeling

Transmission capacity for wholesale transactions 

ELECTRICITY COST
OR PRICE $(\phi / k W h)$
DEMAND RELATIVE
TO PEAK DEMAND

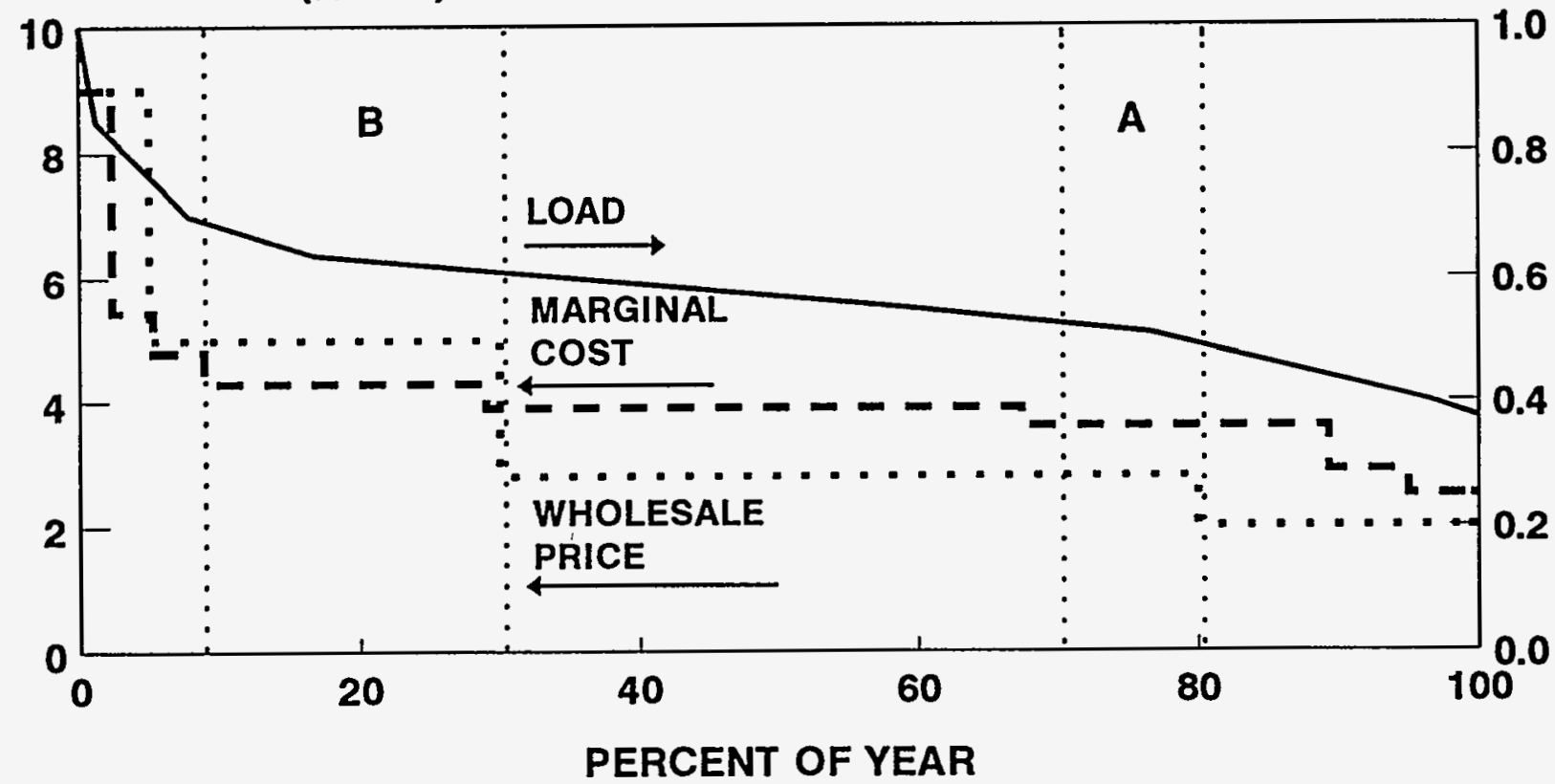

Fig. 5. Load-duration curve, utility marginal production costs, and wholesale spot prices for the ORFIN base-case utility.

During period A, the utility's MC is above the spot price. Therefore, the utility will reduce its generation and purchase enough power on the spot market to meet its retail-customer demand. The amount of power that the utility will buy during this period will depend on the output of the marginal plant (call it Plant 3 ) in the absence of the spot market, any transmission constraints, and the variable costs and outputs of the preceding generating units (i.e., the units operating at that time with variable costs below that of Plant 3 ). In this case, the utility would turn off Plant 3 (with a cost of $3.8 \notin / \mathrm{kWh}$ ) but would continue operating the inframarginal unit (with a cost of $2.8 \notin / \mathrm{kWh}$ ) because the inframarginal unit is no more expensive than the spot price. Thus, the total output of Plant 3 would, during this period, be replaced by the lower-cost spot price. However, if transmission capacity is limited, the utility may not be able to buy as much power as would otherwise be economical.

During period B, the utility's MC is lower than the spot price, so the utility will seek to sell any unused capacity it has. The amount of power that the utility will sell during this period will depend on the unused output of the marginal plant (call it Plant 5), any transmission constraints, and the marginal costs and capacity of the next units (i.e., the units that would be the next to operate if demand increased). In this case, the utility would operate Plant 5 (with a cost of $4.3 \phi / \mathrm{kWh}$ ) at maximum output but would not turn on the next unit because its variable cost of $5.5 \phi / \mathrm{kWh}$ exceeds the spot price at that time of $5.0 \% / \mathrm{kWh}$. As in the prior case, the amount of electricity the utility can sell may be limited by transmission constraints. 
How would these transactions be affected by RW? During period A, either the utility would be producing less with Plant 3 , or Plant 2 (with a variable cost of $2.8 \phi / \mathrm{kWh}$ ) would be on the margin. In the former case, the utility would buy less on the spot market and in the latter case it would neither buy nor sell because the MC of Plant 2 would equal the spot price.

During period B, either the utility would be producing less with Plant 5, or Plant 4 would be on the margin. In the former case, the utility would be able to sell more of the capacity from Plant 5 than in the base case. In the latter case, the utility would sell the unused output of Plant 4 plus all the capacity from Plant 5 . Of course, these amounts could be limited by transmission constraints.

In summary, RW can affect the utility's interactions with the wholesale market in different ways, depending on the relationship between the utility's MC and the spot price (whether the utility wants to sell more or buy less), any differences between the utility's purchase and sale prices for wholesale power, ${ }^{*}$ transmission constraints, and generating capacity constraints.

Returning to Table 5, we consider the specifics of how various factors depend on the wholesale market. Variable production costs determine the utility's MC along each point of the load-duration curve (Fig. 5). Increases in operating costs for individual power plants will reduce the amount of power the utility will sell on the market and will increase the amount of power it will buy. The same is true for the variable portion of power-purchase costs. Changes in wholesale prices have exactly the same effect (with the opposite sign) as do changes in production costs. For example, a decrease in spot prices will reduce the amount of power the utility sells on the market and will increase the amount of power it buys in exactly the same way that an increase in variable costs would. Because of this symmetry between changes in wholesale prices and changes in $\mathrm{MC}$, we show results only for changes in wholesale prices.

Differences between the utility's wholesale purchase and sale prices ( $\Delta$ WS-price) increase the deadband within which the utility neither buys nor sells on the spot market. To illustrate, consider region B in Fig. 5 again. If the utility could sell on the spot market at $0.8 \notin / \mathrm{kWh}$ below what it could purchase, it would neither buy nor sell during this period. Its generation cost of $4.3 \notin / \mathrm{kWh}$ is below the $5.0 \notin / \mathrm{kWh}$ at which it would purchase power and above the $4.2 \notin / \mathrm{kWh}$ at which it could sell power.

Lower outage rates increase the availability of a utility's power plants. Increased availability would lower the utility's variable costs, reducing the losses associated with RW.

*If, for example, the utility can sell on the wholesale market at a price $0.2 \notin / \mathrm{kWh}$ below what it can buy on the market, the utility neither buys nor sells whenever its MC is between its buy and sell prices. Such a buy-sell differential could exist if the utility had to pay for losses or for other ancillary services when it sold power on the spot market. 
Changes in load growth affect wholesale transactions because the energy and capacity requirements for retail customers determine the opportunities the utility has to buy and sell on the market. For example, if loads are higher, the utility will have less discretionary generating capacity to sell on the market. The reduction in the fixed costs of generation associated with higher load growth more than offsets this factor. Including both accounting and wholesalemarket factors, higher load growth reduces SC. For the base case discussed in Chapter 4, an increase in load growth from 1.1 to $2.1 \%$ /year cuts SC by $6 \%$.

Changes in the number of customers that choose to wheel have similar effects; as more customers leave the utility's system, its $\mathrm{MC}$ drops, giving it less need to purchase and more opportunity to sell on the wholesale market. However, transmission constraints increasingly limit the utility's ability to take advantage of wholesale opportunities as the amount of RW increases. And the increase in fixed costs per retail $\mathrm{kWh}$ sold more than offsets the reduction in variable costs. Therefore, the SC losses per wheeling customer increase with the fraction of a utility's load that wheels.

Class load factors and loss factors affect the relationships between customer use and generating requirements and the relationship between energy and demand (the shape of the overall load-duration curve). These changes affect the amount and timing of capacity that a utility can sell or needs to buy on the spot market. Lower load factors increase SC because such loads are more expensive to serve. Higher T\&D losses increase SC for the same reason. The effects of these factors on $\mathrm{SC}$ is a function both of wholesale markets and rate design.

Finally, transmission constraints can limit the amount of purchases and sales that might otherwise be economical. At the limit, with no transmission capacity, the utility would neither buy nor sell, regardless of the relationships between the variable costs of its generating units and spot prices.

Table 6 summarizes this discussion of the relationship between SC estimates and wholesale markets. As wholesale prices increase, the LS-SC estimates decrease (Fig. 6). Indeed, if wholesale prices are sufficiently above the utility's cost of generation, then $\mathrm{SC}$ can be negative (i.e., the utility can earn more money selling on the wholesale market at spot prices than it can selling to its retail customers at embedded-cost prices). This negative relationship between prices and $\mathrm{SC}$ depends on transmission capacity, however. If transmission capacity is low, the amount of SC is nearly invariant with wholesale prices. 


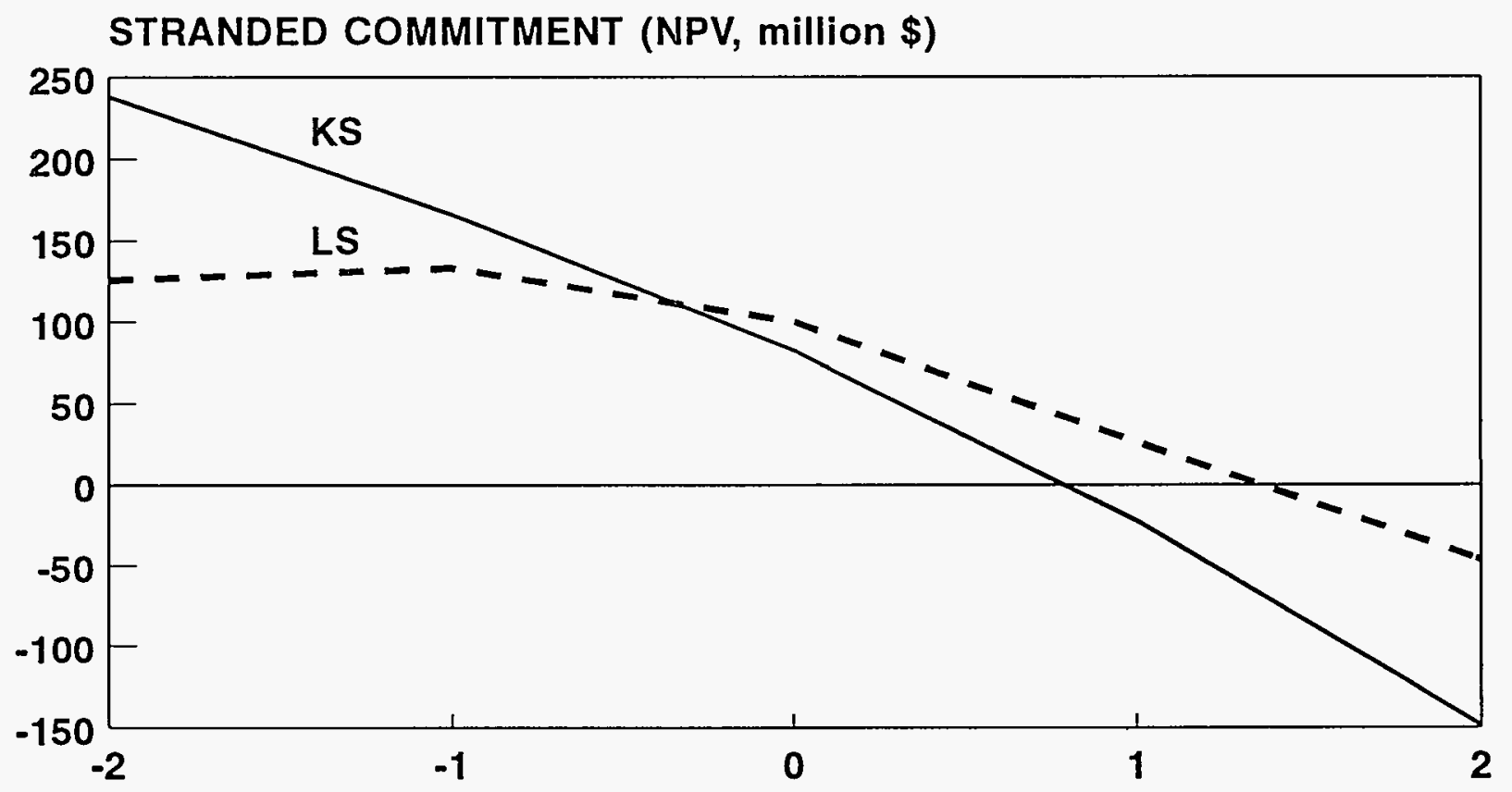

CHANGE IN WHOLESALE PRICE $(\$ / \mathrm{kWh})$

STRANDED COMMITMENT (NPV, million \$)

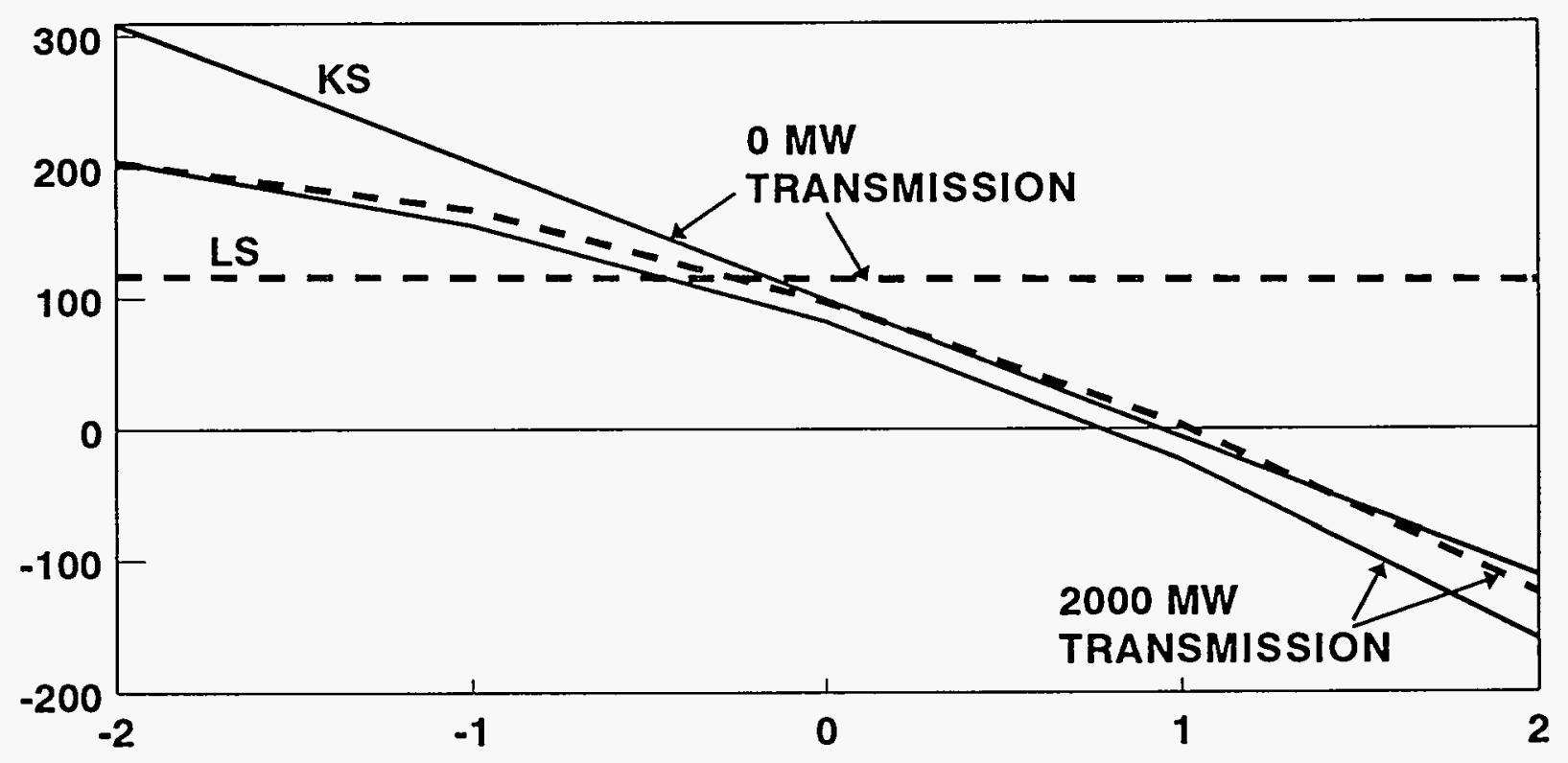

CHANGE IN WHOLESALE PRICE ( $\varnothing / \mathrm{kWh})$

Fig. 6. Effects of changes in wholesale electricity prices on estimates of stranded commitments. The top figure is the base case, and the bottom figure shows results for transmission capacities of 0 and $2000 \mathrm{MW}$. 
Table 6. The effects of increases in different factors related to wholesale power markets on estimates of stranded commitments

\begin{tabular}{|c|c|c|}
\hline \multirow{2}{*}{$\begin{array}{l}\text { Factor } \\
\text { increasing }\end{array}$} & \multicolumn{2}{|c|}{ Effect on stranded commitments if utility: } \\
\hline & Keeps sale & Loses sale \\
\hline $\begin{array}{l}\text { Wholesale } \\
\text { prices }^{\mathrm{a}}\end{array}$ & Decreases & $\begin{array}{l}\text { Decreases for all values of RW and } \\
\Delta W S-\text { price; nearly independent of } \\
\text { wholesale prices at low values of } \\
\text { transmission capacity }\end{array}$ \\
\hline $\begin{array}{l}\text { Transmission } \\
\text { capacity }\end{array}$ & Decreases & $\begin{array}{l}\text { Decreases for all values of } \Delta W S \text {-price } \\
\text { and high values of RW; increases at low } \\
\text { values of RW; increases at low wholesale } \\
\text { prices and decreases at high wholesale } \\
\text { prices }\end{array}$ \\
\hline $\begin{array}{l}\text { Percentage of } \\
\text { customers that } \\
\text { wheel }\end{array}$ & $\begin{array}{l}\text { Increases linearly with } \\
\text { number of RW customers }\end{array}$ & $\begin{array}{l}\text { Increases more rapidly than number of } \\
R W \text { customers }\end{array}$ \\
\hline$\Delta$ WS-price & $\begin{array}{l}\text { No change at low } \\
\text { wholesale prices; increases } \\
\text { at high wholesale prices; } \\
\text { invariant with transmission } \\
\text { constraint and RW }\end{array}$ & $\begin{array}{l}\text { No change at low wholesale prices; } \\
\text { increases at high wholesale prices }\end{array}$ \\
\hline
\end{tabular}

\footnotetext{
${ }^{\text {a }}$ The response to increases in the utility's marginal costs of generation is exactly the opposite of those for increases in wholesale prices.
}

If the utility keeps the sale, its losses also depend on wholesale price. As the wholesale price increases, the utility's loss (Eqn. 1) decreases because the difference between its production cost and wholesale price declines. Because the utility's production cost may depend to some extent on its purchase or sale of electricity to meet native loads, transmission constraints affect SC estimates. However, the effects of transmission constraints in the KS case are much less than in the LS case.

The relationship between LS-SC and transmission capacity depends on the relationship between wholesale prices and utility MC (Fig. 7). When wholesale prices are close to MC, transmission capacity has little effect on SC estimates because there is little profit to be earned on purchases and sales (Eqn. 2). At wholesale prices lower than MC (under which conditions the utility would purchase power), increasing transmission capacity increases the amount of SC. As transmission capacity is increased, the utility will buy as much power as it can up to the transmission limit. However, in the RW case, the utility's MC is lower than in the base case, 
STRANDED COMMITMENTS (NPV, million \$)

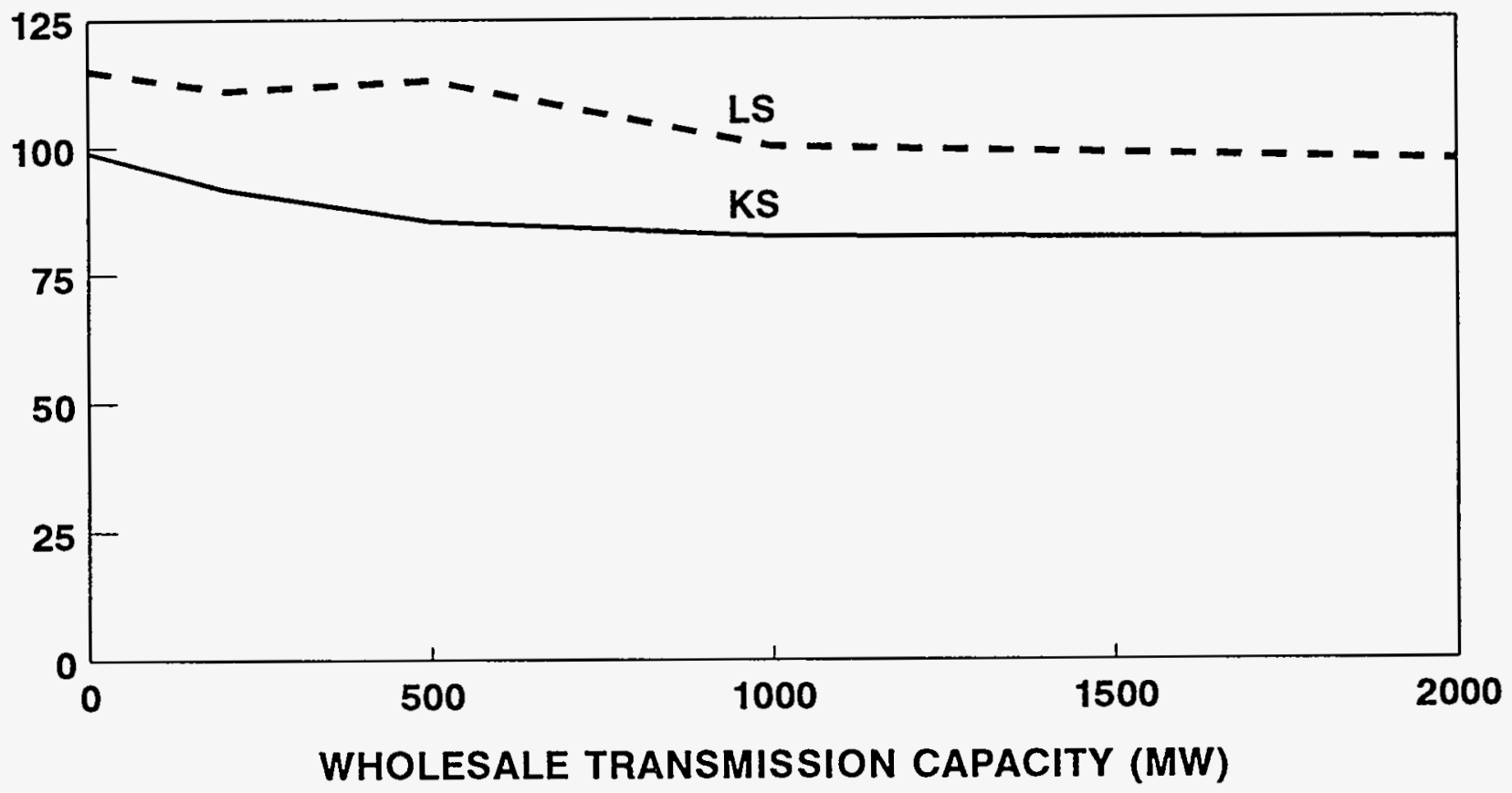

STRANDED COMMITMENTS (NPV, million \$)

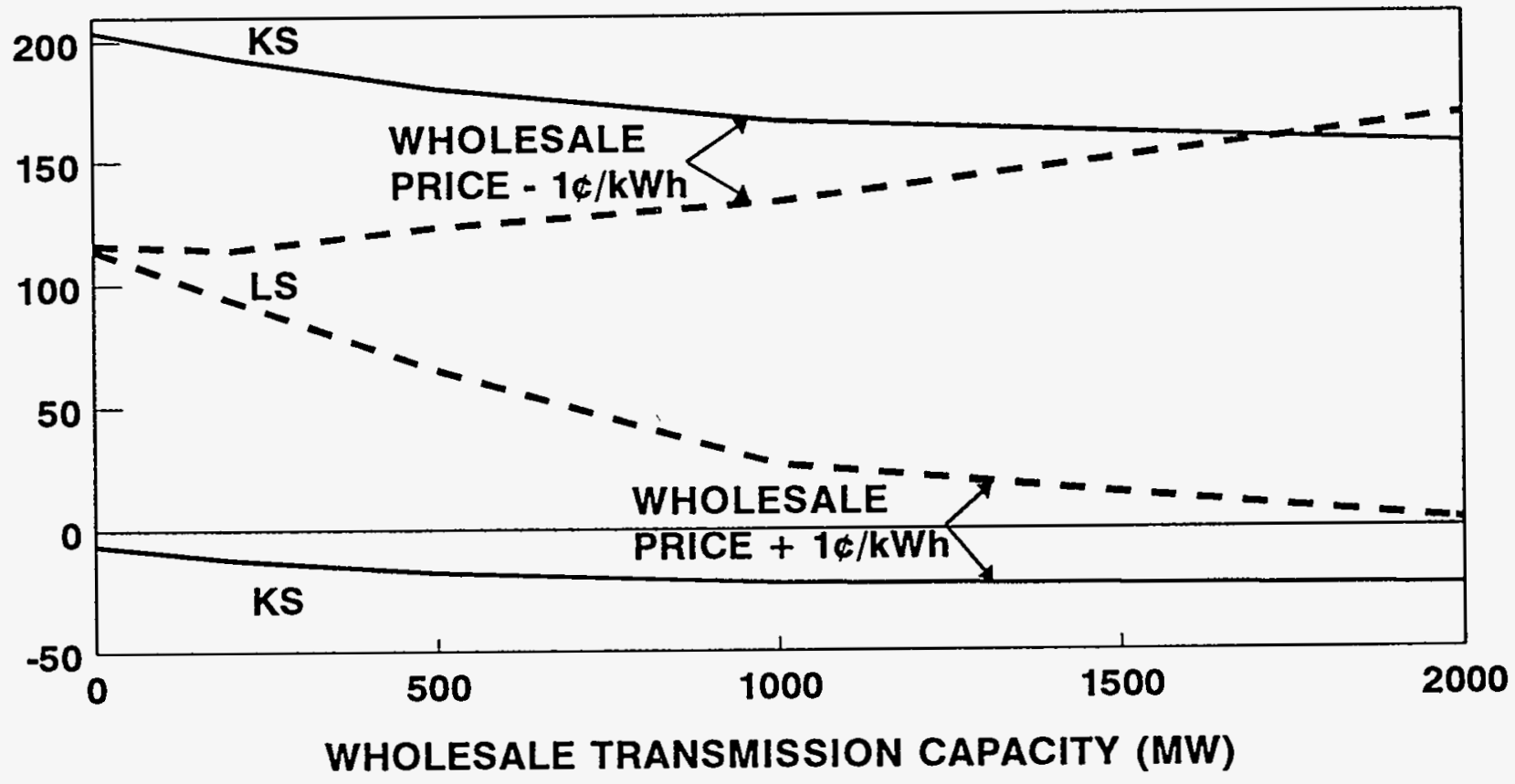

Fig. 7. Effects of changes in transmission capacity on estimates of stranded commitments. The top figure is the base case, and the bottom figure shows results for wholesale prices $1 \notin / \mathrm{kWh}$ above and below the base-case values. 
so it has less need to buy on the spot market. Thus, increases in transmission capacity benefit the base case more than the wheeling case, leading to increases in SC estimates. The reverse is true at higher values of wholesale prices. Here, as the transmission capacity is increased, the utility sells more power. In the RW case, the utility's MC is again lower so it can sell more power on the wholesale market. Thus, at high wholesale prices, the utility earns more money on the spot market with RW than without.

If the utility keeps the sale, its losses depend only slightly on transmission constraints. As explained above, the utility's production costs may depend on its wholesale purchase or sale to meet native loads. The KS and LS estimates are closest to each other when transmission capacity is large (bottom of Fig. 7).

The LS loss increases more than linearly with the number of RW customers. Thus, as the percentage of RW customers increases, the LS-SC loss per wheeling customer increases (Fig. 8). With low wholesale prices, as RW increases, the utility buys less and less (because its MC decreases with increased wheeling) and eventually begins to sell on the spot market. At high values of RW, the utility is unable to sell as much as its MC would suggest because of transmission constraints. As transmission constraints become more binding, the SC loss per RW customer increases. At high spot prices, as wheeling increases, the utility sells more and more until, once again, it reaches the transmission constraint. Beyond this point, the SC losses increase with increases in wheeling. Higher transmission capacity lowers SC for all values of RW.

If the utility keeps the sale, its losses increase linearly with the number of RW customers. Thus, per wheeling customer, the KS losses are invariant with the amount of RW because neither pre-RW production costs nor wholesale prices depend on the amount of RW.

Finally, as the difference between wholesale purchase and sale prices ( $\Delta$ WS-price) increases, LS-SC increases for high values of wholesale price (Fig. 9). At low values of wholesale price, the SC estimates are nearly invariant with price difference because the utility would sell little power on the spot market under these conditions (i.e., its production costs are almost always higher than spot prices). The effects of $\triangle W S$-price on SC are smaller than the effects of the other factors discussed above.

Once again, the KS losses do not depend on the difference between wholesale sale and purchase prices because this factor has no effect on either pre-RW production costs or on wholesale prices. 
STRANDED COMMITMENT (NPV, million \$/10\% RW)

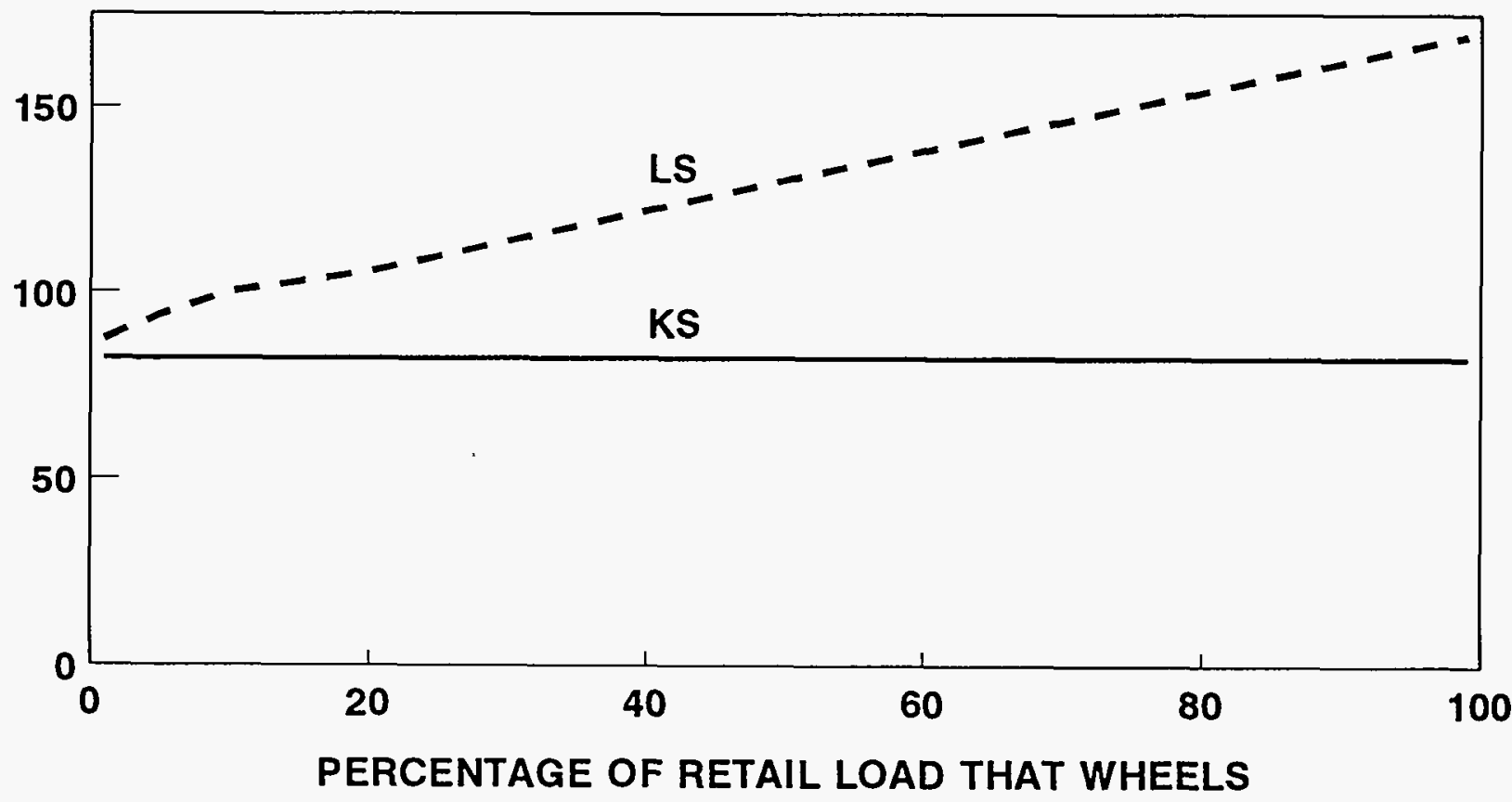

\section{STRANDED COMMITMENT (NPV, million \$/10\% RW)}

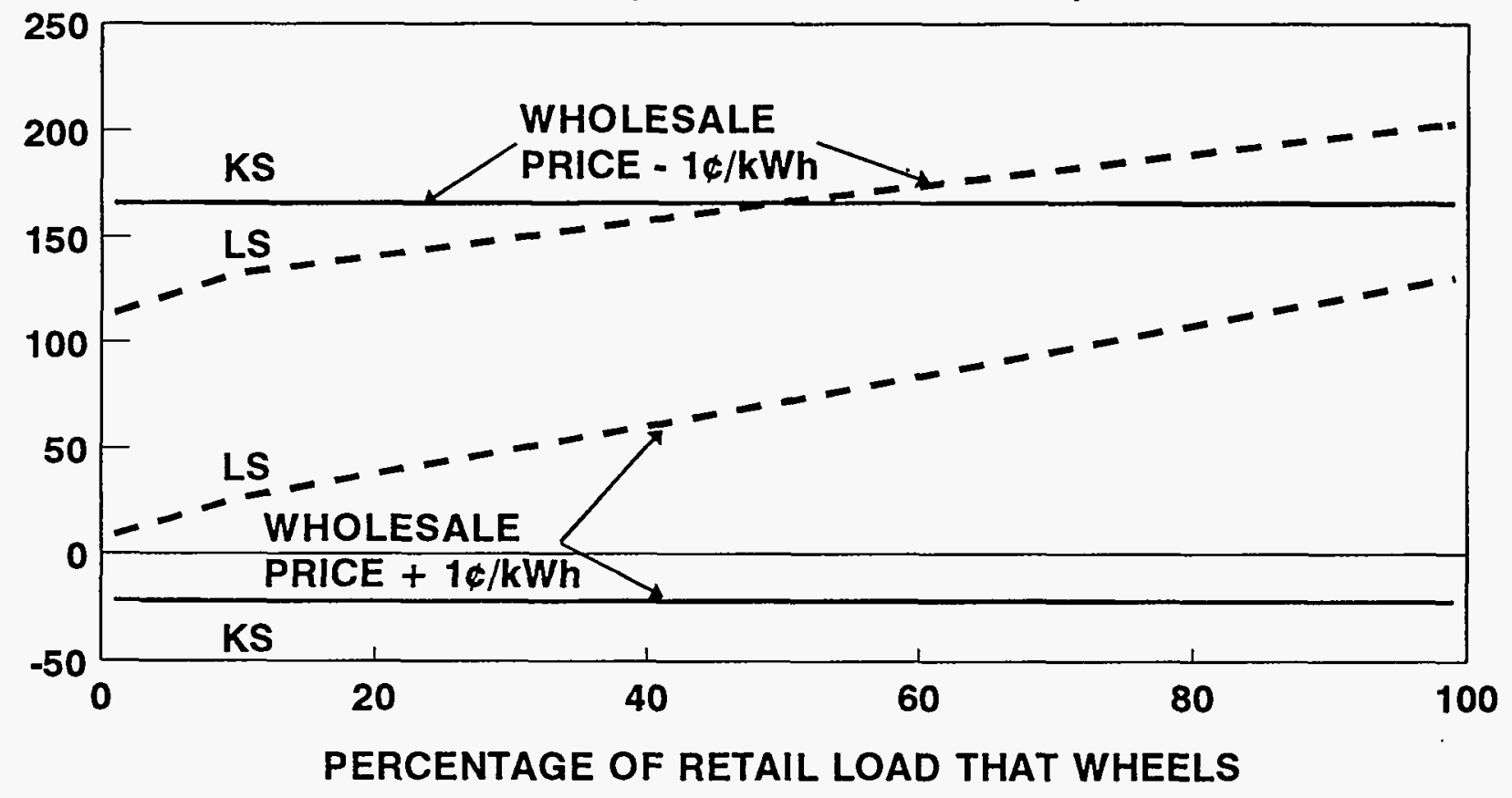

Fig. 8. Effects of the percentage of retail load that chooses wheeling on estimates of stranded commitments (normalized to $10 \%$ retail wheeling). The top figure is the base case, and the bottom figure shows results for wholesale prices $1 / \mathrm{kWh}$ above and below the base-case values. The $\mathrm{y}$ axis is different than that for Figs. 6, 7, and 9. 

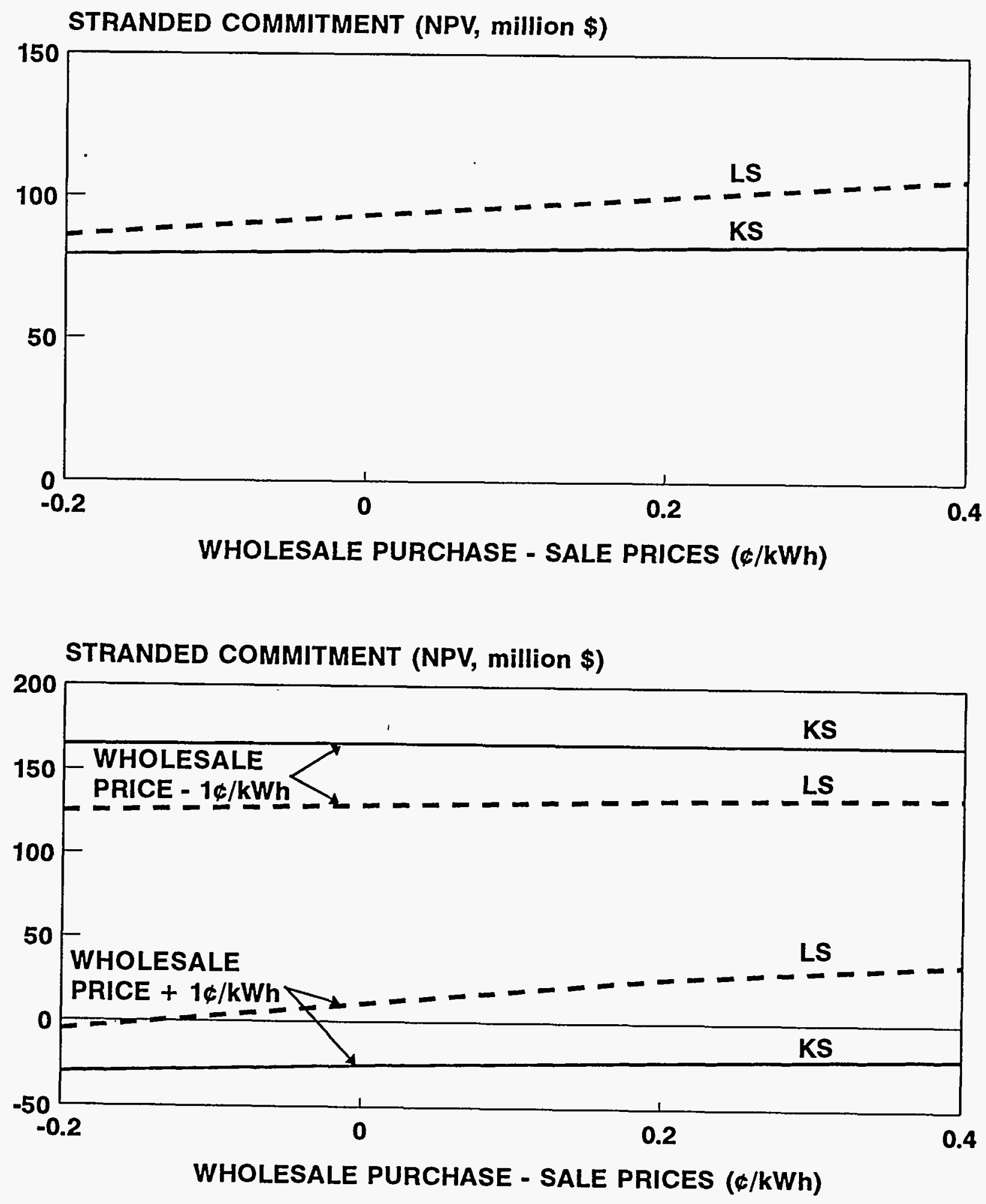

Fig. 9. Effects of the difference between wholesale purchase and sale prices on estimates of stranded commitments. The top figure is the base case, and the bottom figure shows results for wholesale prices $1 / / \mathrm{kWh}$ above and below the base-case values. 


\section{ACCOUNTING FACTORS}

We return now to the accounting factors listed in Table 5. These factors have no effect on the utility's interactions with the wholesale market. Instead, they affect the utility's income statement and balance sheet. Therefore, they have the same effects on the KS and LS results. In addition, decreases and increases in these factors have symmetrical effects on SC estimates, unlike the factors that affect wholesale markets.

Changes in the fixed cost of generation include those factors related to the capital costs of the utility's power plants (initial construction cost, book and tax depreciation rates, property tax, interest payment on bonds, and return on equity) plus the annual fixed O\&M costs. Changes in the fixed costs of utility-owned plants affect SC estimates exactly as do changes in the fixed costs of power-purchase contracts. All these factors are included in the first factor in Table 7. Increasing the fixed-cost component of generation by $\$ 25 / \mathrm{kW}$-year (equivalent to $0.6 \notin / \mathrm{kWh}$ ) increases the SC estimates by $72 \%$ for our base-case utility.

Regulatory assets include a variety of past costs that regulators allow utilities to collect in the future; these costs are all assigned to generation for ratemaking purposes. As identified by the Edison Electric Institute (1994), they include phase-in of newly completed power plants, unrecovered plant costs, and future costs (e.g., decommissioning of nuclear power plants and postretirement benefits for employees). A $50 \%$ increase ( $\$ 50$ million) in these regulatory assets has only a small $(4 \%)$ increase in SC.

Social programs include annual expenses that pay for activities such as special programs for low-income consumers, demand-side management programs, and energy research. Doubling such expenditures (adding $\$ 40$ million/year) increases SC by $11 \%$. Increasing A\&G (overhead) costs has the same effect on $\mathrm{SC}$ as does increases in social-program costs.

General plant capital costs refer to those investments (e.g., office buildings, computers, and vehicles) that support the overall operation of the utility. Doubling these investments (adding $\$ 5$ million/year) each year has only a small (1\%) effect on SC estimates.

Rate design (in particular, the allocation of costs between wheeling and nonwheeling customers) affects SC estimates. The base case requires wheeling customers to pay for a share of $A \& G$ costs assuming that these costs are allocated across generation, transmission, and distribution according to the fixed costs for these three functions. This assumption leads to an allocation of $45 \%$ for wheeling customers. Allocating more of these costs to wheeling customers (e.g., raising the factor from 45 to $60 \%$ ) lowers SC by $10 \%$. Indeed, if wheeling customers paid for these $A \& G$ costs at the same rate as remaining retail customers do, then there would be no change in SC estimates caused by changes in social programs, A\&G annual costs, or general-plant capital costs. 
Finally, inflation affects the rate at which fixed production costs depreciate. Higher inflation rates (assuming that the utility's cost of capital does not change) reduce fixed costs and therefore lead to lower estimates of SC.

Table 7. The effects of various accounting factors on estimates of stranded commitments $^{\mathrm{a}}$

\begin{tabular}{|c|c|c|}
\hline \multirow{2}{*}{ Factor } & \multicolumn{2}{|c|}{ Change in SC } \\
\hline & $\%$ & million $\$$ \\
\hline Fixed production costs $(\$ 140 / \mathrm{kW}-\mathrm{year}),{ }^{\mathrm{b}}+\$ 25 / \mathrm{kW}$-year & 72 & 60 \\
\hline Regulatory assets ( $\$ 100$ million $),+\$ 50$ million & 4 & 3 \\
\hline Social programs ( $\$ 40$ million/year), $+\$ 40$ million/year & 11 & 9 \\
\hline $\begin{array}{l}\text { Administrative \& general costs ( } \$ 80 \text { million/year), } \\
+\$ 40 \text { million/year }\end{array}$ & 11 & 9 \\
\hline $\begin{array}{l}\text { General-plant capital costs ( } \$ 5 \text { million/year), } \\
+\$ 5 \text { million/year }\end{array}$ & 1 & 1 \\
\hline $\begin{array}{l}\text { Allocation of A\&G costs to wheeling customers }(45 \%) \text {, } \\
+15 \text { percentage points }\end{array}$ & -10 & -8 \\
\hline Inflation rate $(3 \% /$ year $),+1 \% /$ year & -4 & -3 \\
\hline
\end{tabular}

${ }^{\mathrm{a}} \mathrm{The} \mathrm{KS}$ and LS estimates of SC in the base case are $\$ 82.4$ and $\$ 100.1$ million, respectively. The absolute effect of the seven factors shown above is the same for both SC estimates. Because of the difference in these two base-case $\mathrm{SC}$ values, the percentage-change figures are not identical; the values shown above are based on the keep-sale calculations.

${ }^{b}$ The numbers in parentheses are the base-case values for each factor (Chapter 4 ). 



\section{WHEN IS IT BETTER TO KEEP THE SALE?}

As discussed in Chapter 3, if it is cheaper for the utility to keep the sale than to lose the sale, one can use a simple TD method to calculate accurately SC losses. On the other hand, if it is cheaper for the utility to lose the sale, then one must use either a TD method that is not accurate or a more detailed BU method to calculate SC losses. Here we explore the conditions under which the KS option is preferred (i.e., results in smaller SC losses than the LS option).

If the utility keeps the sale, its revenues are based on the purchase price for wholesale power. If the utility loses the sale, its resale revenues are based on the sale price for wholesale power, which, in our analyses, is equal to or less than the purchase price. In addition, if the utility loses the sale, it may not be able (because of generation and transmission constraints) to resell all of this capacity and energy on the wholesale market. On the other hand, if the utility loses the sale, it can choose, based on the time-varying relationship between its MCs and wholesale prices, when to buy and sell on the wholesale market.

The results presented in Chapter 5 show that when the wholesale price is higher than the utility's MC; the utility is better off keeping the sale. The results are conditioned by transmission capacity, the percentage of customers that wheel, and the difference between wholesale sale and purchase prices. Generally speaking, the KS option is preferred as wholesale price increases relative to the utility's $\mathrm{MC}$, as the percentage of customers that wheel increases, and as the difference between wholesale purchase and sale prices increases.

KS losses are much more sensitive to changes in wholesale prices than are LS losses (Fig. 6). This greater sensitivity occurs because the KS loss depends directly on the wholesale market price (Eqn. 1). The LS loss also depends on the wholesale price but in a more complicated fashion (Eqn. 2). As the wholesale price increases, the utility's loss caused directly by the departure of retail customers declines. At the same time, however, the additional earnings associated with resale of the energy lost because of RW decline. Because these two factors operate in opposite directions, the LS estimates are much less sensitive to changes in wholesale price than are the KS estimates.

KS losses depend slightly on the amount of transmission capacity available for wholesale transactions (Fig. 7). Increases in transmission capacity lower the utility's production cost by allowing it to buy (at low wholesale prices) or sell (at high wholesale prices) on the spot market. LS losses, on the other hand, depend strongly on the amount of transmission capacity available. For the range of conditions examined here, the relationship between the KS and LS 
estimates is almost independent of transmission capacity. As transmission capacity increases, the KS option is preferred at lower wholesale prices.

KS losses per unit of lost load are completely independent of the fraction of retail load that chooses to wheel (Fig. 8). LS losses, however, increase substantially as the amount of RW increases. At low wholesale prices, the LS option is preferable at low fractions of RW and the $\mathrm{KS}$ option is preferable at high fractions. At high wholesale prices, the KS option is always preferable because the LS loss is higher than the KS loss even at very low RW fractions.

KS losses increase slightly with increases in $\Delta$ WS-price for wholesale prices higher than MC (Fig. 9). The reason for this slight dependence on price difference is the same as that for transmission capacity-increases in the price difference reduce the utility's ability to sell on the spot market, thus raising its production cost slightly. LS losses are much more sensitive to increases in the wholesale-price difference because this difference directly determines the utility's earnings from the resale of RW losses (the second term in Eqn. 2).

Generally, when wholesale prices are above marginal costs, the KS option is preferred. When wholesale prices are below marginal costs, the KS option is preferred only at high levels of RW. 


\section{CONCLUSIONS}

Quantification and recovery of stranded commitments is a key issue in every state that is considering changes in the electricity industry (Eckert 1995). This attention to stranded commitments is a consequence of the large dollar amounts that will be transferred among utility shareholders, customers, and taxpayers. Therefore, utilities, regulatory commissions, and electricity consumers need to agree on appropriate methods to calculate stranded commitments. These costs are typically associated with utility-owned generating units and power-purchase contracts whose book values exceed market values. Stranded commitments also include regulatory assets and societal programs. These are costs "that would be recovered under the existing regulatory regime, but would not be recovered in a fully open retail market" (Niagara Mohawk 1995).

The amount of stranded commitment a utility will face depends on whether the utility keeps the sale at risk of retail wheeling or loses the sale. The SC calculation when the utility keeps the sale is simple. However, if the utility loses the sale, the SC calculation is more complicated. The complications arise because of the interactions between the utility's generating resources and the wholesale power market.

This distinction between the KS and LS options leads us to categorize the factors that affect SC according to whether they affect the wholesale power market or accounting factors. Those that affect wholesale markets are crucial to the determination of the LS option and are the source of the complications noted above. Variable production costs, wholesale-power prices, and transmission constraints are examples of wholesale-market factors. Fixed generating costs (initial cost, depreciation, taxes, and fixed O\&M); public-policy programs; and income-tax rates are examples of accounting factors.

We defined and explained two classes of models that can be used to estimate the amount of SC a utility will face, top-down and bottom-up. TD methods are simple to apply, whereas the BU methods, because of their inherent detail, are data and labor intensive. TD methods are suitable for estimating stranded commitments at the regional and national levels. Bottom-up methods will likely be required to analyze utility-specific SC issues as a prerequisite to allocation of these costs among different entities.

Although the BU approach presented here is much more complicated than the TD approach, it does not incorporate all the factors that can affect SC estimates. For example, both approaches ignore the likely dynamic interactions between changes in industry structure and 
regulation on the one hand and wholesale markets and prices on the other hand. In reality, wholesale prices will depend on regulatory and utility decisions concerning industry structure and treatment of stranded commitments. In addition, electricity demand is a function of electricity prices. Changes in industry structure and regulation that affect electricity prices will affect demand. These changes in demand will then affect stranded commitments. The time period over which to compute stranded commitments is a difficult policy decision, especially if SC is positive for a few years and then turns negative (see the results for 2005 in Fig. 4). Finally, if utilities writeoff uneconomic generating assets, the tax and operating implications will be substantial. The income-tax effects of such write-offs can be quite complicated. And the removal of some generating units from operational status would affect wholesale markets and prices.

Our parametric analyses showed that the KS option is usually preferred when wholesale prices are above the utility's marginal production cost, as the percentage of customers that wheels increases, and as the difference in wholesale purchase and sale prices increases. Under those conditions, when the KS loss is less than the LS loss, one can use a TD approach to obtain an accurate estimate of SC losses.

However, when the LS loss is less than the KS loss, the TD methods do not yield accurate estimates. We examined a variety of TD-LS methods but were unable to find ones that consistently gave results close to those obtained with a BU method. Thus, one must resort to the BU approaches when the LS option is preferred.

Our analysis of the factors affecting SC estimates showed that wholesale prices (or their equivalent, the utility's marginal production costs) and the utility's fixed production costs have the largest effects (Fig. 10). The KS estimates are more sensitive to changes in wholesale price, fixed production costs, regulatory assets, and social programs than are the LS estimates. On the other hand, the KS estimates are relatively insensitive to differences between wholesale purchase and sale prices and on a per-customer basis are independent of changes in the fraction of retail load that wheels. 


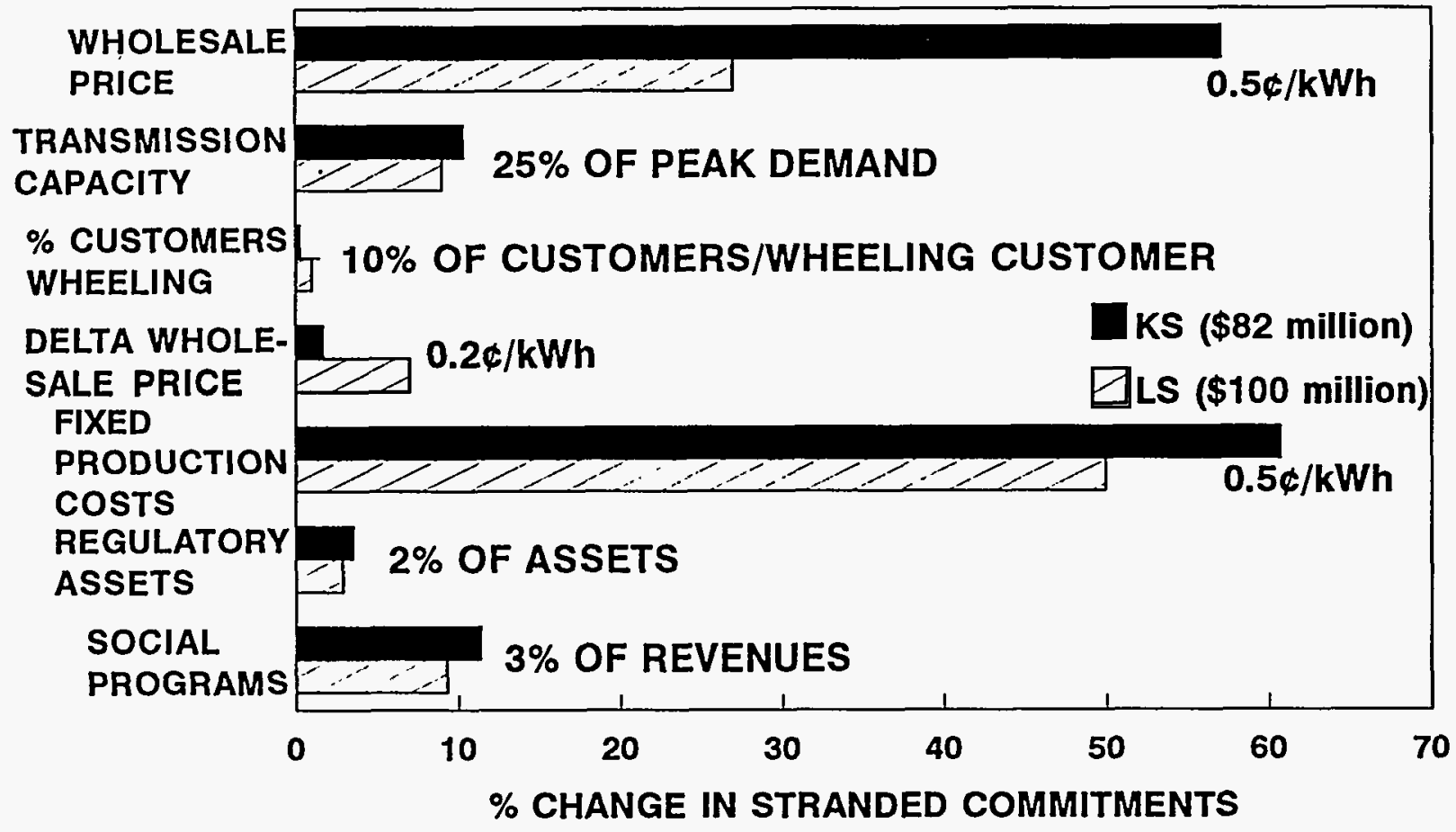

Fig. 10. The effects of changes in various factors around their base-case values on estimates of stranded commitment. Base-case values of stranded commitment are \$82.4 million for the keep-sale option and \$100.1 million for the lose-sale option.

\section{ACKNOWLEDGMENTS}

We thank Thomas Austin, Gregory Basheda, David Berry, Thomas Broderick, Paul Centolella, Michael Foley, Michael Griffin, Louis Harris, James Hoffsis, John Leana, Kenneth Rose, David Shutes, and Ruben Tavares for their very helpful comments on a draft of this report. We thank Val Jensen for his continuing support throughout this project. Finally, we thank Fred O'Hara for editing this report and Ethel Schorn for managing the clearance, printing, and distribution of this report. 
(1) 


\section{REFERENCES}

L. Baxter and E. Hirst 1995, Estimating Potential Stranded Commitments for U.S. InvestorOwned Electric Utilities, ORNL/CON-406, Oak Ridge National Laboratory, Oak Ridge, TN, January.

L. Baxter 1995, Different Approaches to Estimating Transition Costs in the Electric-Utility Industry, ORNL/CON-423, Oak Ridge National Laboratory, Oak Ridge, TN, October.

J. Chamberlin 1981, Costs and Rates Workbook, ICF, Inc., prepared for the Electric Utility Rate Design Study, Electric Power Research Institute, Palo Alto, CA, September.

J. Eckert 1995, Competition Tracking Report, National Renewable Energy Laboratory, Washington, DC, October.

Edison Electric Institute 1994, Initial Comments of Edison Electric Institute, submitted to the Federal Energy Regulatory Commission in Docket No. RM94-7-000, Washington, DC, December 7.

Energy Information Administration 1995a, Financial Statistics of Major U.S. Investor-Owned Electric Utilities 1993, DOE/EIA-0437(93)/1, U.S. Department of Energy, Washington, DC, January.

Energy Information Administration 1995b, Annual Energy Outlook 1995, DOE/EIA-0383(95), U.S. Department of Energy, Washington, DC, January.

Energy Information Administration 1995c, Electric Power Annual 1994 Volume I, DOE/EIA0348(94)/1, U.S. Department of Energy, Washington, DC, July.

E. Hirst and S. Hadley 1994, Effects of Resource Acquisitions on Electric-Utility Shareholders, ORNL/CON-387, Oak Ridge National Laboratory, Oak Ridge, TN, May.

R. J. Matlock 1995, An Assessment of the Potential for Stranded Investment in Texas, Texas Public Utility Commission, Austin, TX, August.

New York Public Service Commission 1995, Staff Position Paper, Case 94-E-0952, Albany, NY, October 25. 
Niagara Mohawk Power Corp. 1994, The Impacts of Emerging Competition in the Electric Utility Industry, Syracuse, NY, April.

Niagara Mohawk Power Corp. 1995, Multi-Year Electric Rate, Restructuring and Retail Access Proposal, Case Nos. 94-E-0098 and 94-E-0099, Before the New York Public Service Commission, Syracuse, NY, October.

Resource Data International 1994, Retail Power Markets in the U.S., Boulder, CO.

San Diego Gas \& Electric Company 1994, Comments of San Diego Gas \& Electric Company on Proposed Policies Governing Restructuring Electric Services Industry and Reforming Regulation, submitted to the California Public Utilities Commission in Docket No. R.94-04031, San Diego, CA, June 8.

U.S. Federal Energy Regulatory Commission 1995, Promoting Wholesale Competition Through Open Access Non-discriminatory Transmission Services by Public Utilities, Recovery of Stranded Costs by Public Utilities and Transmitting Utilities, Docket Nos. RM95-8-000 and RM94-7-001, Washington, DC, March 29.

Vermont Competition Work Group 1995, Statement of Workgroup Principles, Docket No. 5854, Before the Vermont Public Service Board, Montpelier, VT, July 17.

M. W. White 1995, Valuing Market Trading Mechanisms: Evidence from Electricity Markets, PWP-033, Program on Workable Energy Regulation, University of California, Berkeley, CA, August.

A. J. Wood and B. F. Wollenberg 1984, Power Generation, Operation, and Control, John Wiley \& Sons, New York, NY. 


\section{INTERNAL DISTRIBUTION}

1. D. Bauer

2. L. Baxter

3. V. D. Baxter

4. L. Berry

5. D. S. Bjornstad

6. R. Braid

7. M. A. Brown

8. J. Christian

9. G. Courville

10. T. R. Curlee

11. P. D. Fairchild

12. S. Hadley

13. L. J. Hill

14. E. Hillsman

15. E. Hirst

16. P. J. Hughes

17. B. Kirby

18. R. Lee

19. P. Leiby
20. J. M. MacDonald

21. V. C. Mei

22. D. E. Reichle

23. D. T. Rizy

24. A. C. Schaffhauser

25. M. Schweitzer

26. R. B. Shelton

27. J. Tomlinson

28. B. E. Tonn

29. J. Van Dyke

30. J. Vancoevering

31. J. M. Veigel (ORAU)

32. T. J. Wilbanks

33. ORNL Patent Office

34. Central Research office

35. Document Reference Section

36. Laboratory Records (RC)

37-39. Laboratory Records Dept.

\section{EXTERNAL DISTRIBUTION}

40. Dr. Thomas E. Drabek, Professor, Department of Sociology, University of Denver, Denver, CO 80208-0209

41. Dr. Stephen G. Hildebrand, Director, Environmental Sciences Division, Oak Ridge National Laboratory, Post Office Box 2008, Oak Ridge, TN 37831-6037

42. Mr. George F. Sowers, P. E., Senior Vice President, Law Companies Group, Inc., 114 Townpark Drive, Suite 250, Kennesaw, GA 30144-5599

43. Dr. C. Michael Walton, Ernest H. Cockrell Centennial Chair in Engineering and Chairman, Department of Civil Engineering, University of Texas at Austin, Austin, TX 78712-1076

44.-46. OSTI, U. S. Department of Energy, P. O. Box 62, Oak Ridge, TN 37831

47. Office of Assistant Manager for Energy Research and Development, DOE/ORO, P. O. Box 2001, Oak Ridge, TN 37831-8600

48.-675. External Electric Industry Policy Studies group distribution mailing list and extra copies to E.M. Schorn, $4500 \mathrm{~N}, \mathrm{H}-19 \mathrm{~A}$ 


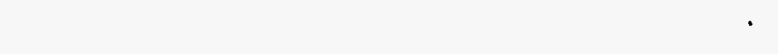

